\title{
Enhancement of Thermal Comfort Inside the Kitchen of Non-Airconditioned Railway Pantry Car
}

\author{
Md Sarfaraz Alam*, Urmi Ravindra Salve \\ Department of Design, Indian Institute of Technology Guwahati, Guwahati 781039, Assam, India
}

Corresponding Author Email: sarfaraz8665@iitg.ac.in

https://doi.org/10.18280/ijht.390131

Received: 7 July 2020

Accepted: 21 October 2020

\section{Keywords:}

SET index, computational fluid dynamics, energy, comfort temperature, ventilation, thermal sensation, chefs

\begin{abstract}
There are ample literature studies available, focusing on hot-humid built environment, which have achieved an increase in thermal comfort conditions by proper installation of ventilation-systems. The present thermal comfort study has been carried out in the kitchen environment of a non-air-conditioned railway pantry car in Indian Railways. The purpose is to enhance thermal comfort level under the currently applied ventilation system inside the kitchen of pantry car by determining the standard effective temperature (SET) index. During the summer and winter seasons, a field study was carried out to obtain the value of air temperature, globe temperature, relative humidity, and air velocity inside the pantry car for estimation of the SET index. A computational fluid dynamics (CFD) analysis was used to obtain a better-modified case model of the pantry car kitchen for the improvement of thermal comfort. The design interventions for the pantry car kitchen were created, with emphasis on increasing energy efficiency based on low-power consumption air ventilation system. The study results indicated that, modified case-I model has a better ventilation design concept as compare to the existing and other models, which increased the air velocity and significantly decreased the air temperature inside the kitchen of pantry car at all cooking periods. A value of SET $\left(28.6-30^{\circ} \mathrm{C}\right)$ was found with a comfortable thermal sensation within all cooking periods, which is better for the pantry car workers. This finding suggests a sustainable improvement in the thermal environment of the "non-airconditioned" pantry car kitchen in the Indian Railways, which can be applied immediately.
\end{abstract}

\section{INTRODUCTION}

Generally, the commercial kitchen environment is very hot and moist during the working period [1-3]. Which railway pantry car is usually a kind of kitchen where many workers work together [4]. According to the railway board report 2015, 338 pairs of trains are run with pantry cars. Which provides the meal to every onboard passenger. In a one pantry car coach has 4-5 chefs, 40-50 waiters, and 2 pantry staff [4-6]. As per the previous research by Alam et al. [7] directed the hot and humid harsh environment has a significant impact on the chef's health and work efficiency in the pantry car kitchen due to less air movement and high temperature. Unfortunately, these issues are caused by poor ventilation systems that directly influence the chef's thermal comfort inside the pantry car kitchen.

Typically, thermal comfort can affect the worker's perception rates, productivity, and health [8-10]. Based on ASHRAE Standard 55 [11], "thermal comfort is the condition of mind which expresses satisfaction with the thermal environment". Previous studies suggested, six major factors have an effect on thermal comfort which four environmental factors like; "air temperature, globe temperature, air velocity, and relative humidity", and two personal factors like; "metabolic rate, and clothing insulation" [12-14]. By combining these six factors, we can determine the "thermal comfort".

As per the literature, there are varieties of indices available to estimate thermal comfort in indoor environments such as; "Predicted Mean Vote-PMV", "Predicted Percentage Dissatisfied-PPD", "Standard Effective Temperature-SET", "Discomfort Index-DI", other too [15-17]. Every thermal comfort index has some limitations based on the input parameters. Currently, the PMV and PPD indices are commonly used by researchers in the building-environment [18-20]. But few thermal comfort studies in commercial kitchen environments state that PMV is not suitable for predicting thermal comfort due to high temperatures and high metabolic rates [21, 22]. However, a small study was conducted by Alam et al. [4] on the kitchen environment of the railway pantry car at the time of the cooking period based on objective evaluation during the summer season. In that research, the value of "PMV and PPD" index was found 2.93 and $99 \%$ respectively. Similarly, another thermal comfort study was conducted by Alam et al. [7] on the railway pantry car kitchen with a large sample size during summer and winter seasons based on the "physical measurement and subjective assessment". The results of this also indicate that "PMV and PPD" index is not applicable for a thermal comfort application due to high temperature and less air movement. They have proposed a comfort temperature for pantry car chefs based on the adaptive analysis for the summer season $\left(18.50-27.80^{\circ} \mathrm{C}\right)$ and winter season $\left(17.80-25.50^{\circ} \mathrm{C}\right)$.

The research of Zhou et al. [23] in China explains that reduced air-temperature by implementing a "push-pull ventilation system" that could improve the thermal comfort of 
workers living inside the kitchen. Another study in China conducted by Chen et al. [24] on commercial kitchen with computational fluid dynamics (CFD) in that indicated the discharge rate $14 \mathrm{~m}^{3} \cdot \mathrm{min}^{-1}$, is capable to remove fumes to outdoors and suggested increasing the exhaust fan volume will reduce the dissatisfactory rate of human thermal sensation. Similarly, in Malaysia research conducted by Mansoor et al. [25] on thermal comfort in a commercial kitchen environment to improve the "ventilation system". The results of this study referred to that if supply air increases then the temperature will decrease at the cooking zone and recommended $0.28 \mathrm{~m} / \mathrm{s}$ airvelocity supply inside the kitchen for thermal comfort. Because the high air supply does not apply to the kitchen environment. In Bangladesh, a study carried out by Hamidur Rahman and Sadrul Islam [26] on the urban residential kitchen using the CFD simulation and identified the effect of the different position of hood suction for the improvement of thermal comfort. As a consequence of the study, both the front and bottom hood outlet concepts were found to be superior for thermal comfort.

While Malek et al. [27] investigated the thermal comfort condition on naturally ventilated buildings in Malaysia base on field measurement and CFD approach. They found good agreement between simulated and field measurement data. For thermal comfort enhancement, only air temperature and air velocity have been tested for simulation analysis. Similarly in the United States, Nazarian et al. [28] researched the improvement of thermal comfort over urban environments using the SET index in CFD simulation analysis. In China also at the hot and humid climate for occupant's thermal comfort inside the residence same SET index was used [29]. Accordingly, in Singapore Shetty et al. [30] have researched hot and moist environments using energy-efficient fans. Used the SET index based on the "ASHRAE 55" standard to assess the thermal comfort of occupants in the building for energysaving and compared it to field measurement data [30].

The present study describes the outcomes of thermal comfort research at the various cooking period in the kitchen of the non-airconditioned railway pantry car in India. The aim is to appraise the SET thermal sensation ranges under the currently applied ventilation system. The CFD simulation was used to predict the distribution of supply, air temperature, and air velocity inside the pantry car kitchen. Parametric studies were carried out to identify the high-performance modification of pantry car kitchens that would help increase thermal comfort.

\section{METHOD}

\subsection{Details of the non-airconditioned pantry car kitchen}

The existing situation of the non-airconditioned kitchen of the Indian railway pantry car is depicted in Figure 1 (a) and (b). As shown in Figure 2, non-airconditioned pantry cars are usually rectangular shaped with the length $(\mathrm{L})$, width $(\mathrm{W})$, and height $(\mathrm{H})$ is $22.29 \mathrm{~m}, 3.24 \mathrm{~m}$, and $3.11 \mathrm{~m}$, respectively. There are four doors on both sides and seventeen windows on the opposite side of the kitchen area, however, around eleven windows on the kitchen side-wall. The dimensions of the kitchen area are approximate, $\mathrm{L}=8.10 \mathrm{~m}, \mathrm{~W}=2.20 \mathrm{~m}$, and $\mathrm{H}=3.11 \mathrm{~m}$. As discussed in previous studies, four or five chefs work in this kitchen area [4]. No ventilation system is included in this pantry car to reduce indoor hot air, and the air velocity has also been found to be very low, according to previous studies [7].

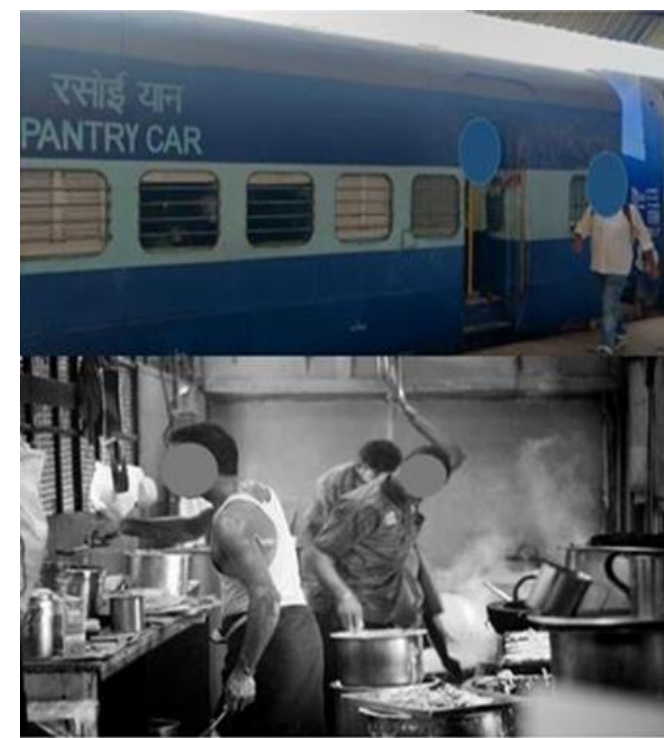

(a)

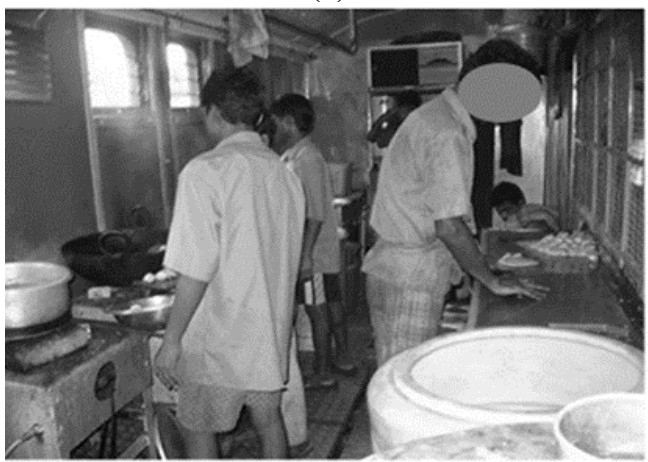

(b)

Figure 1. Existing model of non-airconditioned pantry car kitchen (a) and (b).

http://www.iieta.org/pdf-viewer/7216

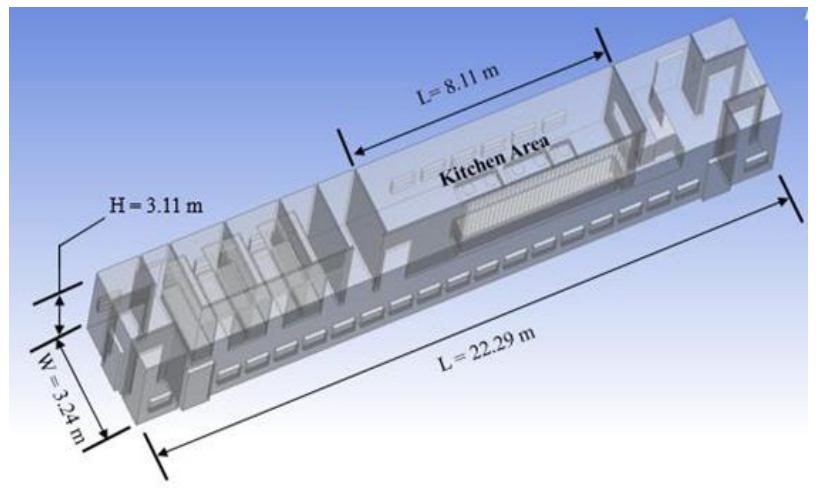

Figure 2. Description of the non-airconditioned pantry car

\subsection{Field measurement}

Figure 3 shows the measuring point inside the kitchen area of the pantry car, where the following parameters were measured, such as; "air temperature- Ta, globe temperature$\mathrm{Tg}$, relative humidity-RH, and air velocity-Va". During the field study, the data were taken with the help of an instrument at $1.1 \mathrm{~m}$ above the floor height and $0.3 \mathrm{~m}$ near to the cooking area during summer and winter seasons. All data were taken 
in a pantry car during the cooking period of "breakfast (7:00 am), lunch (11:30 am), snack (4:00 pm), and dinner (6:30 pm)", and it recorded for 10-15 minutes at intervals of 10 seconds. The detailed description "range and accuracy" of the instrument are depicted in Table 1 . These devices have already been used by the authors in previous thermal comfort research on railway pantry car kitchens to identify chef's comfort ranges $[4,31]$.

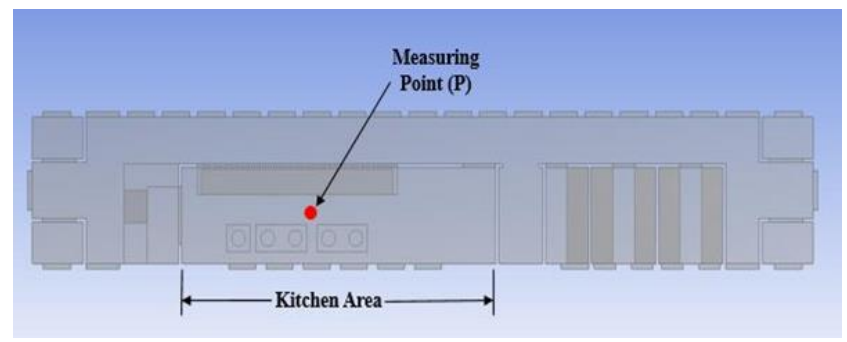

Figure 3. Location of field measurement data collection point

Table 1. Detail description of measuring instrument

\begin{tabular}{cccc}
\hline Factors & Instrument & \multicolumn{2}{c}{ Description } \\
\cline { 3 - 4 } & & Accuracy & Ranges \\
\hline $\mathrm{Ta}$ & Kestrel & $-5^{\circ}$ to $+95^{\circ} \mathrm{C}$ & $29.0^{\circ} \mathrm{C}$ to $+50.0^{\circ} \mathrm{C}$ \\
$\mathrm{RH}$ & weather & $\pm 3 \%$ & $5 \%$ to $95 \%$ \\
$\mathrm{Va}$ & $\begin{array}{c}\text { meter } \\
\text { model- } 4500\end{array}$ & $\pm 0.1 \mathrm{~m} / \mathrm{s}$ & $0.4 \mathrm{~m} / \mathrm{s}$ to $60 \mathrm{~m} / \mathrm{s}$ \\
\hline $\mathrm{Tg}$ & $\begin{array}{c}\text { 6-inch } \\
\text { black-globe } \\
\text { thermometer }\end{array}$ & $\mathrm{NA}$ & $-5^{\circ}$ to $+95^{\circ} \mathrm{C}$ \\
& & \\
\hline
\end{tabular}

\subsection{SET index calculation}

The SET "Standard effective temperature" is the "rational physiologically" based index of thermal comfort, which was developed by ASHRAE. The determination of SET requires six input parameters, including four environmental parameters like; "air temperature, radiant temperature, relative humidity, air velocity", and two individual parameters namely "metabolic rate and clothing level". In this study, CBE thermal comfort software was adopted to assess the SET index based on the "ASHRAE-55 2017". Table 2 showing the thermal sensation ranges values based on the SET index [15].

Table 2. SET thermal sensation ranges

\begin{tabular}{cc}
\hline Category & Thermal sensation \\
\hline$<17$ & Cool \\
$17-30$ & Comfortable \\
$30-34$ & Warm \\
$34-37$ & Hot \\
$>37$ & Very Hot \\
\hline
\end{tabular}

According to a previous thermal comfort study on the railway pantry car by Alam et al. [7], the metabolic activity level and clothing value of pantry car chefs have been assumed to be 1.5 to 2.0 (met) and 0.5 to 0.58 (clo), respectively. However, for the simulation analysis in this study, the mean radiant temperature was assumed to be equal to the air temperature and the relative humidity is taken to be between $50-60 \%[4,7]$. Because the CFD simulation has difficulty in estimating these parameters, therefore it was taken as per the previous study.

\subsection{CFD modelling and simulation}

Present research "computational fluid dynamics-CFD" technique was incorporated to demonstrate the flow simulation to estimate the air temperature and airflow velocity dispensation inside the kitchen of the railway pantry car. This technique was also applied to predict the thermal comfort estimation of pantry cars based on the parametric study to recognize the appropriate strategy to enhance thermal comfort. Solid works 2015 wad used to construct the 3D-model of the railway pantry car kitchen as depicted in Figure 4, and then the model (in igs file format) was imported in the ANSYS fluent R14.5 version software.

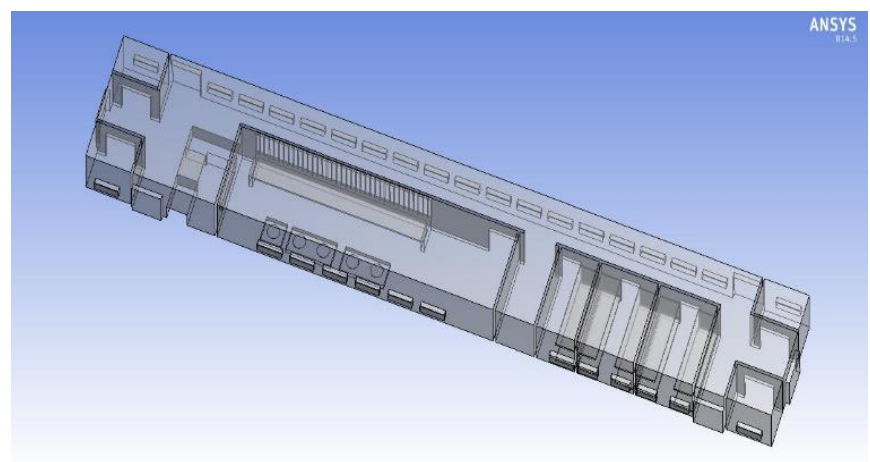

Figure 4. 3D-model of the railway pantry car kitchen

Governing equations of fluid dynamics viz., mass, momentum, and energy equations were used to the discretization of the model.

Conservation of mass

$$
\begin{gathered}
\frac{\partial \rho}{\partial t}+\frac{\partial \rho u_{i}}{\partial x_{i}}=0 \\
\left(\frac{\partial u}{\partial x}+\frac{\partial u}{\partial y}+\frac{\partial u}{\partial z}\right)=0 \\
\frac{\partial \rho}{\partial t}+\frac{\partial \rho u}{\partial x}+\frac{\partial \rho v}{\partial y}+\frac{\partial \rho w}{\partial z}=0
\end{gathered}
$$

Conservation of momentum:

For each dimension when the velocity is $\mathrm{V}(\mathrm{u}, \mathrm{v}, \mathrm{w})$

The X-momentum equation

$$
\begin{aligned}
\rho\left(u \frac{\partial u}{\partial x}+v \frac{\partial u}{\partial y}\right. & \left.+w \frac{\partial u}{\partial z}\right) \\
& =-\frac{\partial p}{\partial \mathrm{x}}+\mu\left(\frac{\partial^{2} u}{\partial x^{2}}+\frac{\partial^{2} u}{\partial y^{2}}+\frac{\partial^{2} u}{\partial z^{2}}\right)
\end{aligned}
$$

The $\mathrm{Y}$-momentum equation

$$
\begin{aligned}
\rho\left(u \frac{\partial v}{\partial x}+v \frac{\partial v}{\partial y}\right. & \left.+w \frac{\partial v}{\partial z}\right) \\
& =-\frac{\partial p}{\partial y}+\mu\left(\frac{\partial^{2} v}{\partial x^{2}}+\frac{\partial^{2} v}{\partial y^{2}}+\frac{\partial^{2} v}{\partial z^{2}}\right)
\end{aligned}
$$


The Z-momentum equation

$$
\rho\left(u \frac{\partial w}{\partial x}+v \frac{\partial w}{\partial y}+w \frac{\partial w}{\partial z}\right)=-\frac{\partial p}{\partial z}+\mu\left(\frac{\partial^{2} w}{\partial x^{2}}+\frac{\partial^{2} w}{\partial y^{2}}+\frac{\partial^{2} w}{\partial z^{2}}\right)
$$

Conservation of Energy:

$$
\begin{aligned}
\left(\frac{\partial}{\partial t}(\rho T)+\frac{\partial}{\partial x}(\rho U T)+\frac{\partial}{\partial y}(\rho V T)+\frac{\partial}{\partial z}(\rho W T)\right) \\
=\frac{\partial}{\partial \mathrm{x}}\left(\Gamma \frac{\partial \mathrm{T}}{\partial \mathrm{x}}\right)+\frac{\partial}{\partial \mathrm{y}}\left(\Gamma \frac{\partial \mathrm{T}}{\partial \mathrm{y}}\right)+\frac{\partial}{\partial \mathrm{z}}\left(\Gamma \frac{\partial \mathrm{T}}{\partial \mathrm{z}}\right)
\end{aligned}
$$

where, ui -velocity of fluid xi ( $i=1,2,3), \rho$-air density, $\mu$ dynamic viscosity, $\mathrm{P}$-effective density, $\Gamma$-diffusion coefficient, and $T$-Coolant temperature $\left({ }^{\circ} \mathrm{C}\right)$.

According to the literature the "k-epsilon RNG" turbulence flow model is included for simulation analysis that is more suitable for kitchen environments [32-36]. In particular tetrahedral volume, elements were used for the lattice of the CFD model. However, the patch conforming technique was included to develop the mesh with a "fine relevance center" [37]. Finer meshing at particular specific regions of importance like doors, air vents, exhaust, burner, fan using fine size meshing and face sizing meshing. The total number of nodes and elements of the mesh model is 99786 and 523873, respectively. The ultimate mesh model of the railway pantry car kitchen is demonstrated in Figure 5.

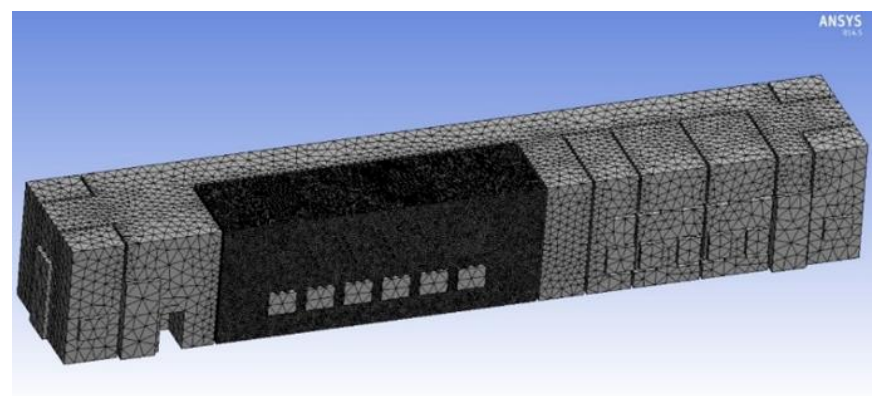

Figure 5. Mesh model of the railway pantry car kitchen

Table 3 cataloged the boundary conditions of the entire cooking period in the pantry car during the winter and summer season. The inward air velocity is considered in boundary conditions as air coming from the left and right sides of the door. However, both the front and opposite side of the kitchen window was considered closed, as chefs tend to close the windows on each side of the kitchen while cooking, as reported by Alam et al. [4]. Therefore, "air temperature and air velocity" were recorded near the same specified doors. Whereas the heat source was taken as the burner temperature according to the workload of different cooking times, which was assumed based on the standard gas burner temperature limit [38]. As earlier study indicated that the busiest and hottest cooking period inside the kitchen of pantry car at lunch and snack, while breakfast and dinner cooking had lower temperatures [7]. We have calculated the temperature of the burner accordingly. The burner has been also considered as a velocity inlet having varying temperatures concerning the cooking time.

The iterations were carried out until the desired convergence was achieved for all the equations/parameters. In this study, the convergence criteria of the energy equation were taken as $10^{-6}$, while for all others equations the convergence criteria were considered as $10^{-4}$ according to the literature $[10,35,39]$.

Table 3. Boundary conditions of the entire cooking period in the pantry car

\begin{tabular}{cccc}
\hline \multicolumn{4}{c}{ Boundary Conditions } \\
\hline \multicolumn{4}{c}{ Summer Season } \\
\hline $\begin{array}{c}\text { Cooking } \\
\text { period }\end{array}$ & Air temperature & $\begin{array}{c}\text { Air } \\
\text { velocity }\end{array}$ & $\begin{array}{c}\text { Burner } \\
\text { temperature }\end{array}$ \\
\hline Breakfast & $301 \mathrm{~K}\left(27.8^{\circ} \mathrm{C}\right)$ & $0.2 \mathrm{~m} / \mathrm{s}$ & $755 \mathrm{~K}\left(481.8^{\circ} \mathrm{C}\right)$ \\
Lunch & $304 \mathrm{~K}\left(30.8^{\circ} \mathrm{C}\right)$ & $0.15 \mathrm{~m} / \mathrm{s}$ & $905 \mathrm{~K}\left(631.8^{\circ} \mathrm{C}\right)$ \\
Snacks & $303 \mathrm{~K}\left(29.8^{\circ} \mathrm{C}\right)$ & $0.15 \mathrm{~m} / \mathrm{s}$ & $823 \mathrm{~K}\left(549.8^{\circ} \mathrm{C}\right)$ \\
Dinner & $302 \mathrm{~K}\left(28.8^{\circ} \mathrm{C}\right)$ & $0.30 \mathrm{~m} / \mathrm{s}$ & $905 \mathrm{~K}\left(631.8^{\circ} \mathrm{C}\right)$ \\
\hline \multicolumn{4}{c}{ Winter Season } \\
\hline Breakfast & $296 \mathrm{~K}\left(22.8^{\circ} \mathrm{C}\right)$ & $0.25 \mathrm{~m} / \mathrm{s}$ & $755 \mathrm{~K}\left(481.8^{\circ} \mathrm{C}\right)$ \\
Lunch & $300 \mathrm{~K}\left(26.8^{\circ} \mathrm{C}\right)$ & $0.3 \mathrm{~m} / \mathrm{s}$ & $905 \mathrm{~K}\left(631.8^{\circ} \mathrm{C}\right)$ \\
Snacks & $298 \mathrm{~K}\left(24.8^{\circ} \mathrm{C}\right)$ & $0.2 \mathrm{~m} / \mathrm{s}$ & $823 \mathrm{~K}\left(549.8^{\circ} \mathrm{C}\right)$ \\
Dinner & $297 \mathrm{~K}\left(23.8^{\circ} \mathrm{C}\right)$ & $0.1 \mathrm{~m} / \mathrm{s}$ & $905 \mathrm{~K}\left(631.8^{\circ} \mathrm{C}\right)$ \\
\hline Exhaust mass flow rate: 1.2 to $1.5 \mathrm{~kg} / \mathrm{s}$ \\
Fan speed: $1200 \mathrm{rpm}$ to $1500 \mathrm{rpm}$ \\
Solver model: k-epsilon $\mathrm{RNG}$ model \\
Number of elements: 523873 \\
Number of nodes: 99786 \\
\hline
\end{tabular}

The CFD model of the pantry car was validated by comparing the measured value of air temperature and air velocity at the measuring point of the pantry car kitchen (Figure 3) with the corresponding values acquired from the simulation analysis. Table 4 and Table 5 correspondingly demonstrate the comparison between measured and simulated data of "air temperature and air velocity" based on the percentage difference during summer and winter seasons.

Table 4. Comparison of measured and simulated air temperature

\begin{tabular}{ccccc}
\hline Seasons & Cooking & Measured & Simulated & $\begin{array}{c}\text { \% } \\
\text { Difference }\end{array}$ \\
\hline \multirow{3}{*}{ Summer } & Breakfast & 30.92 & 30.20 & 2.35 \\
& Lunch & 33.85 & 32.66 & 3.57 \\
& Snacks & 33.22 & 32.80 & 1.27 \\
& Dinner & 31.40 & 30.86 & 1.73 \\
\hline \multirow{3}{*}{ Winter } & Breakfast & 26.85 & 26.20 & 2.45 \\
& Lunch & 31.70 & 31.22 & 1.52 \\
& Snacks & 29.75 & 29.50 & 0.84 \\
& Dinner & 27.65 & 27.15 & 1.82 \\
\hline
\end{tabular}

Table 5. Comparison of measured and simulated air velocity

\begin{tabular}{ccccc}
\hline Seasons & Cooking & Measured & Simulated & $\begin{array}{c}\% \\
\text { Difference }\end{array}$ \\
\hline \multirow{3}{*}{ Summer } & Breakfast & 0.033 & 0.038 & 14.08 \\
& Lunch & 0.00 & 0.00 & 0.00 \\
& Snacks & 0.017 & 0.015 & 12.50 \\
& Dinner & 0.050 & 0.046 & 8.33 \\
\hline \multirow{3}{*}{ Winter } & Breakfast & 0.040 & 0.046 & 13.95 \\
& Lunch & 0.088 & 0.080 & 9.50 \\
& Snacks & 0.013 & 0.011 & 16.60 \\
& Dinner & 0.00 & 0.00 & 0.00 \\
\hline
\end{tabular}

The percentage difference in "air temperature and air velocity" in both seasons was found to be less than 5\% and $20 \%$, respectively, which is good agreement with the data according to the ASHRAE-55 standard [10, 27]. As reported in the research of Noman et al. [10], for complex geometry $20 \%$ error between measured and simulated data is agreeable 
for flow simulation analysis based on the "ASHRAE Standard$55^{\prime \prime}$.

Table 6. Modification of the cases of pantry car kitchen

\begin{tabular}{|c|c|c|c|c|}
\hline \multirow[b]{2}{*}{ Cases } & \multicolumn{2}{|c|}{ Number } & \multicolumn{2}{|c|}{ Location } \\
\hline & $\begin{array}{c}\text { Exhaust } \\
\text { fans }\end{array}$ & $\begin{array}{l}\text { Carriage fans } \\
\text { and Air-vent }\end{array}$ & $\begin{array}{c}\text { Exhaust } \\
\text { fans }\end{array}$ & $\begin{array}{l}\text { Carriage fans } \\
\text { and Air-vent }\end{array}$ \\
\hline I & 4 & 2 & $\begin{array}{l}\text { Front } \\
\text { wall }\end{array}$ & Roof \\
\hline II & 4 & 2 & $\begin{array}{l}\text { Front } \\
\text { wall }\end{array}$ & $\begin{array}{l}\text { Right \& left } \\
\text { side wall }\end{array}$ \\
\hline III & 4 & 4 (air vents) & $\begin{array}{l}\text { Front } \\
\text { wall }\end{array}$ & $\begin{array}{l}\text { Lower side } \\
\text { front wall }\end{array}$ \\
\hline IV & 4 & 3 & $\begin{array}{l}\text { Front } \\
\text { wall }\end{array}$ & $\begin{array}{l}\text { Bottom } \\
\text { surface }\end{array}$ \\
\hline
\end{tabular}

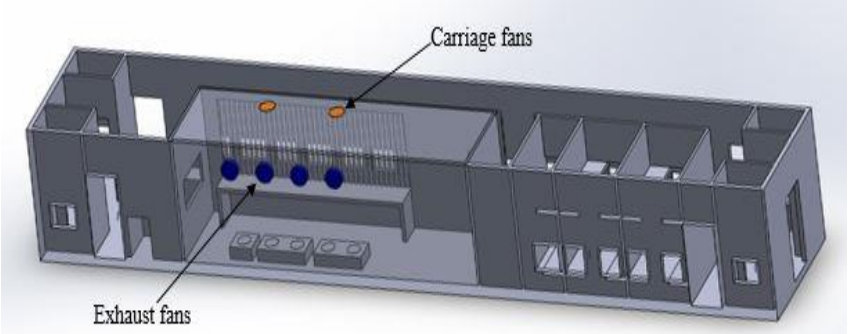

Case I

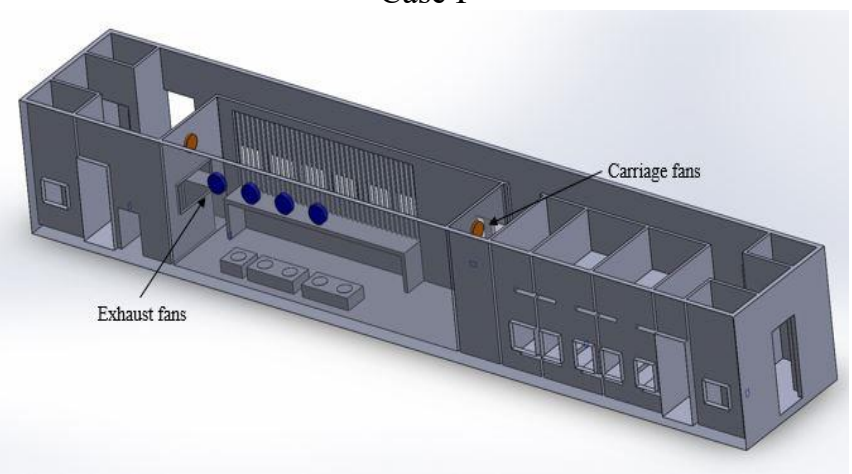

Case II

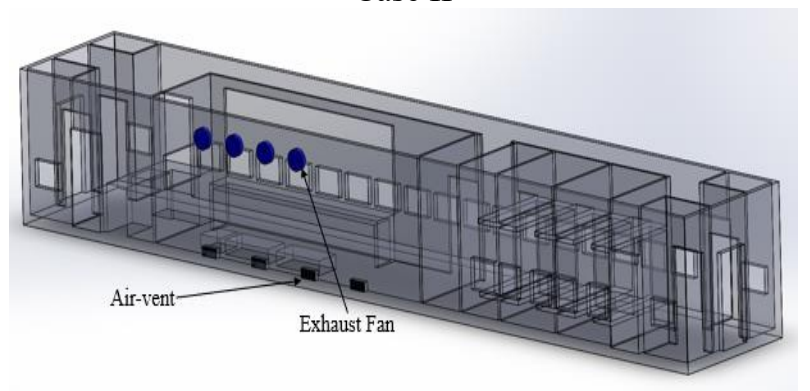

Case III

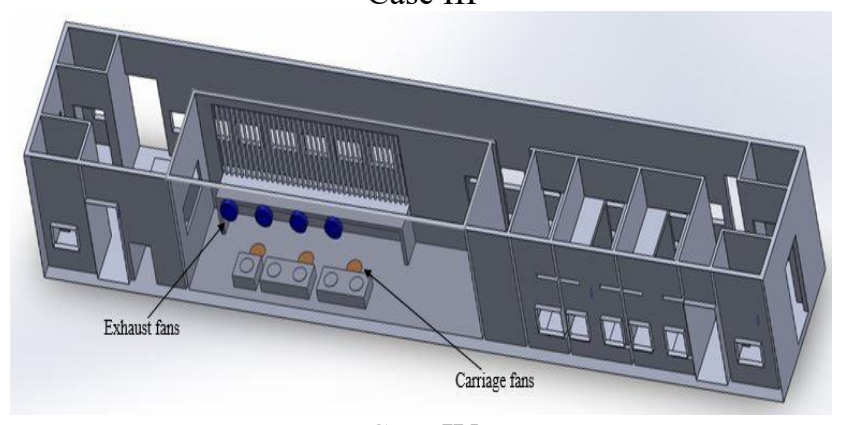

Case IV

Figure 6. Various modification cases - Case-I, Case- II, Case-III, and Case-IV
Previous thermal comfort studies suggested that indoor thermal comfort can be effectively increased by improving the ventilation system [40]. A proper ventilation system helps to maintain the distribution of air temperature and airflow velocity inside the workplace. The study of Noman et al. [10] directed the installation of the four exhaust fan on the wall of the workplace to help enhance thermal comfort. Another researcher Kamar et al. [41], informed that thermal comfort can increase by installing ten exhaust fans on the wall with different air supplies of the normal/typical wall fan because these implementations are convenient and can implement immediately. While it also does not consume much power. Therefore according to the literature in this study, four exhaust fans have been considered with different air supply positions of carriage fans and air-vent see (Table 6). Four different cases of pantry car kitchens were considered, which are shown in Figure 6 and Table 6.

For all cases, the exhaust fan's airflow velocity was considered according to the ASHARE standard 55 [42, 43]. In this study, $450 \mathrm{~mm}$ diameter of exhaust fan was taken, which is readily available in the market. The simulation was performed by placing it $2 \mathrm{ft}(609.6 \mathrm{~mm})$ below the roof on the front wall of the kitchen, and the distance between the two exhaust fans was taken up to $950 \mathrm{~mm}$. Case-I includes two carriage fans with a diameter of $400 \mathrm{~mm}$ at a distance of 670 $\mathrm{mm}$ from the wall on the roof, while the difference between the two carriage fans was $1900 \mathrm{~mm}$. Similarly, at a distance of $609.60 \mathrm{~mm}$ from the roof, the same size of the carriage fan was fitted in Case-II on the left and right side of the kitchen. Whereas in case-III, $97.49 \times 209.32 \mathrm{~mm}$ size of air-vent used at the lower side of the front wall, and the distance between two vents was $1500 \mathrm{~mm}$. In Case-IV also, the same size of carriage fans was installed on the bottom surface, while here, the distance between the two fans was $1900 \mathrm{~mm}$.

The present research objective to find out the distribution of air temperature and air velocity inside the pantry car kitchen area for all cases and to compare them with the current situation. The values of air temperature and air velocity acquired from the CFD analysis were used to calculate the new values of 'SET'. After that, the values of 'SET' compared with the values of the existing case and to assess the appropriate design modifications for improving thermal comfort.

\section{RESULTS AND DISCUSSION}

In this study, all four modified cases have been numerically simulated by the ANSYS Fluent R14.5 software for the redistribution of air supply and exhaust systems inside the kitchen of the pantry car. The consequences of the air temperature and air velocity within the pantry car kitchen has been taken $1.1 \mathrm{~m}$ above the bottom surface and $0.3 \mathrm{~m}$ distance from the stove where the chefs work. Figure 7 and Figure 8 shows case I, summer and winter seasons (i) air temperature and (ii) air velocity distribution profile of CFD at various cooking periods; (a) breakfast, (b) lunch, (c) snacks, and (d) dinner. In this case, during the summer season, the maximum distribution values of air temperature $\left(27.8^{\circ} \mathrm{C}\right)$ were predicted at lunch-time. While minimum temperature $\left(27.1^{\circ} \mathrm{C}\right)$ at breakfast time. However, maximum $(0.19 \mathrm{~m} / \mathrm{s})$ and minimum $(0.13 \mathrm{~m} / \mathrm{s})$ values of air velocity distribution were simulated at dinner and lunch, time respectively. Similarly, in the winter season, the maximum value of air temperature $\left(25.7^{\circ} \mathrm{C}\right)$ was simulated at lunch-time, and the minimum temperature $\left(22.8^{\circ} \mathrm{C}\right)$ was found at dinner time. However, the maximum 
$(0.15 \mathrm{~m} / \mathrm{s})$ and $\operatorname{minimum}(0.11 \mathrm{~m} / \mathrm{s})$ values of air velocity were rooted at lunch and snack time respectively. Uniformly, Figure 9 and Figure 10 demonstrates the case II, summer and winter seasons air temperature and air velocity distribution profile at different cooking periods. In the summer season, at snacks and breakfast period air temperature values were found to be maximum $\left(30.89^{\circ} \mathrm{C}\right)$ and minimum $\left(28.16^{\circ} \mathrm{C}\right)$, respectively.

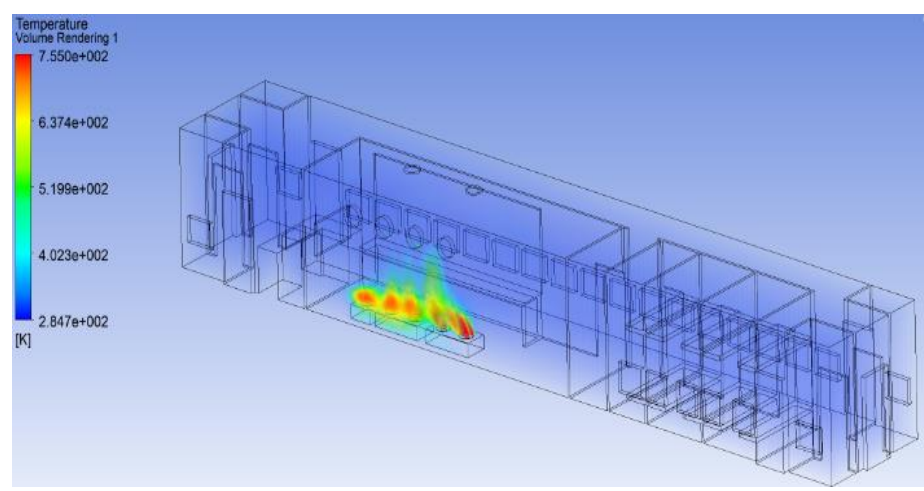

(a)

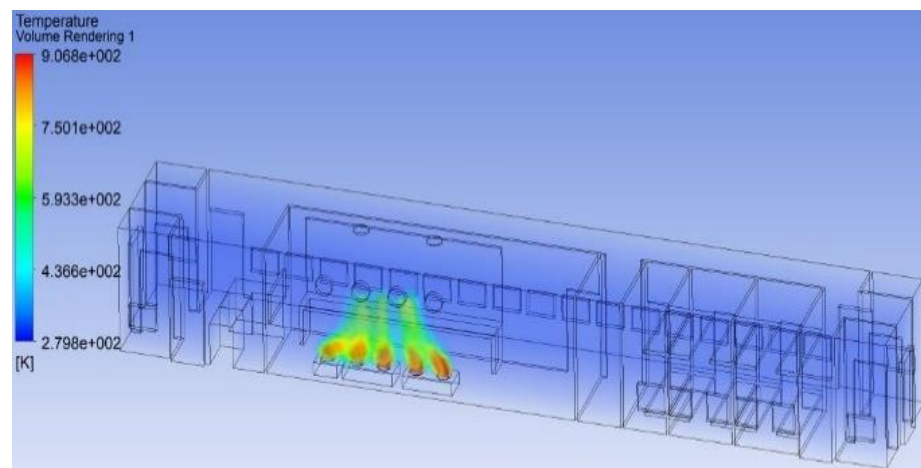

(b)

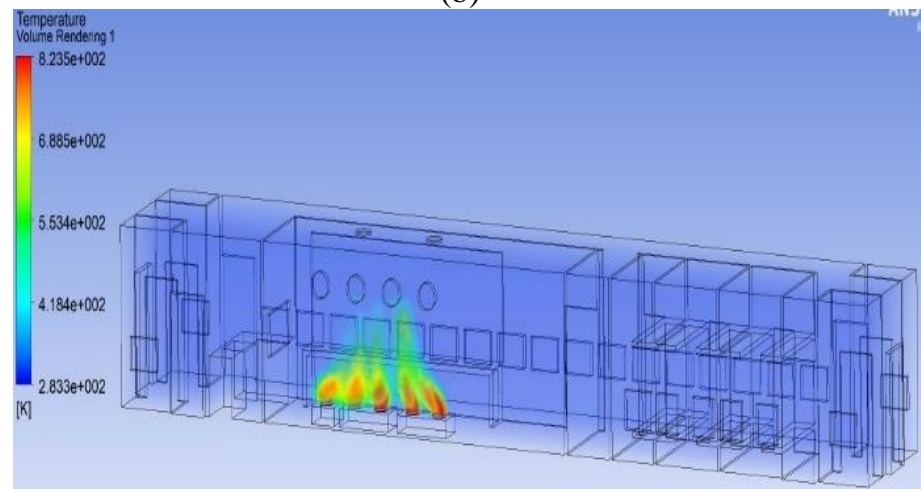

(c)

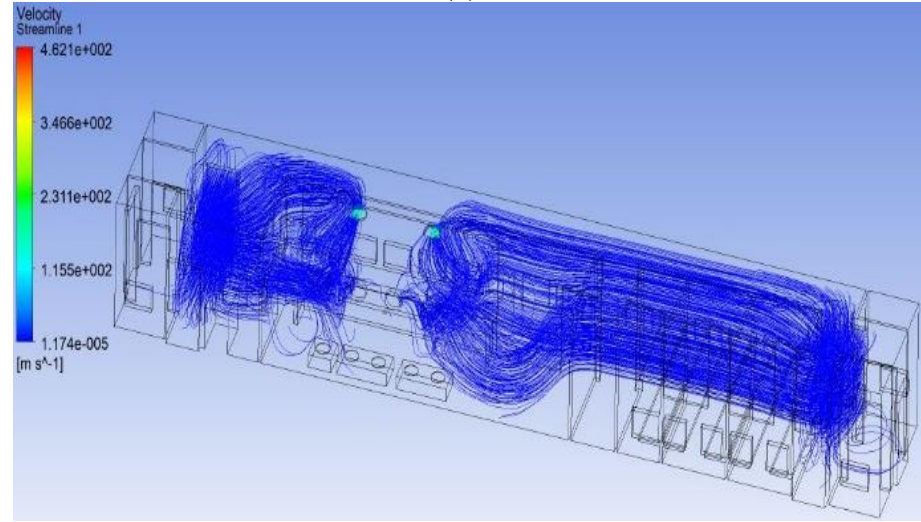

(d)

(i) Air temperature distribution profile
Parallel values of wind velocity were calculated as maximum $(0.15 \mathrm{~m} / \mathrm{s})$ at dinner and minimum $(0.06 \mathrm{~m} / \mathrm{s})$ at lunch. In the winter season, the maximum $\left(29.8^{\circ} \mathrm{C}\right)$ air temperature was found at dinner time and the minimum $\left(22^{\circ} \mathrm{C}\right)$ at breakfast. The value of air velocity has been found the highest at $0.12 \mathrm{~m} / \mathrm{s}$ respectively at the time of breakfast and lunch, while the minimum values were $0.08 \mathrm{~m} / \mathrm{s}$ at dinner.

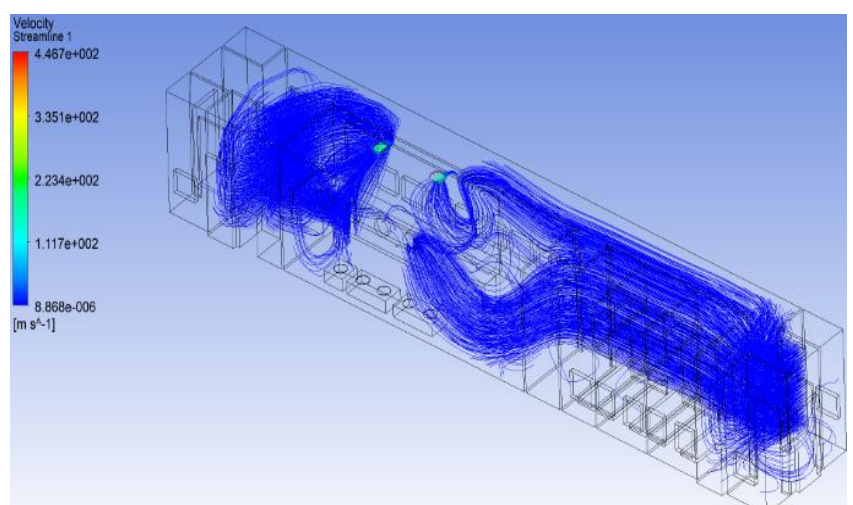

(a)

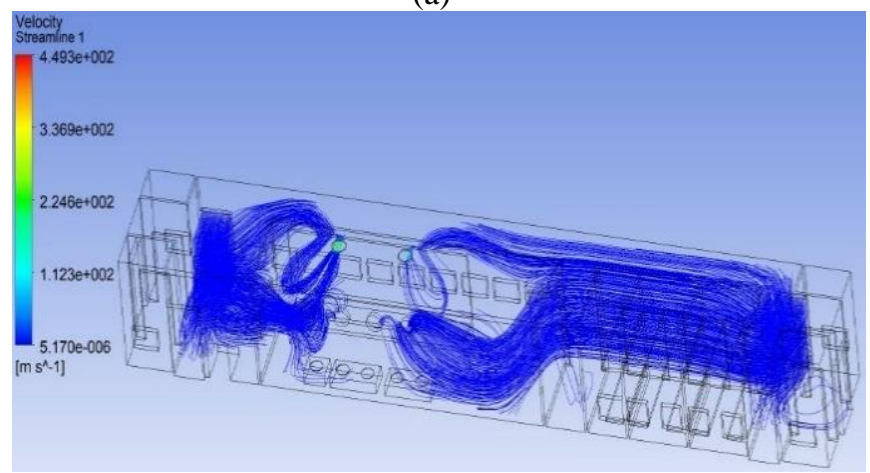

(b)

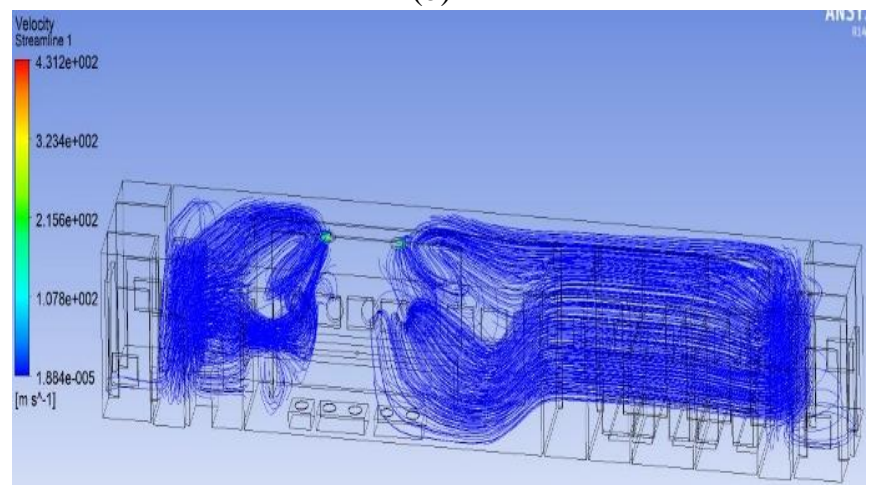

(c)

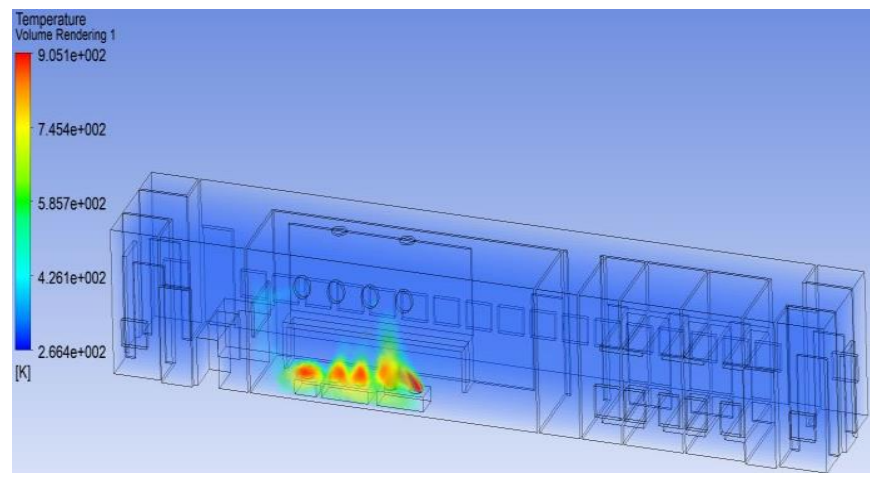

(d)

(ii) Velocity distribution profile

Figure 7. Case I, summer season (i) air temperature and (ii) velocity, distribution profile of CFD at various cooking period; (a) breakfast, (b) lunch, (c) snacks, and (d) dinner 


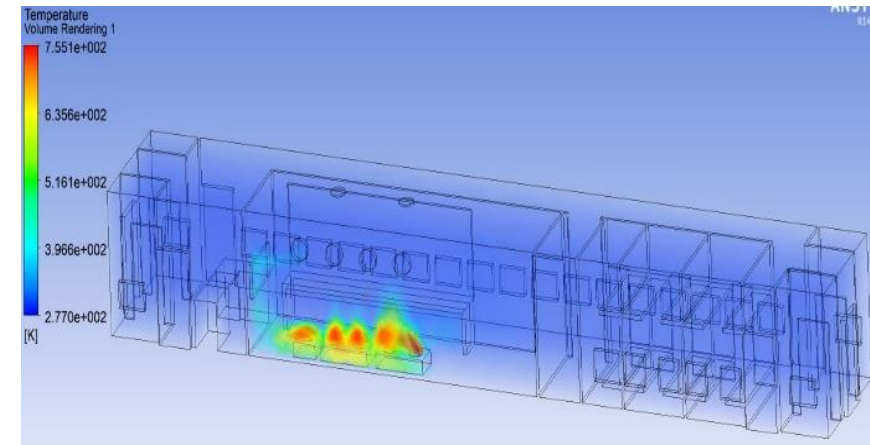

(a)

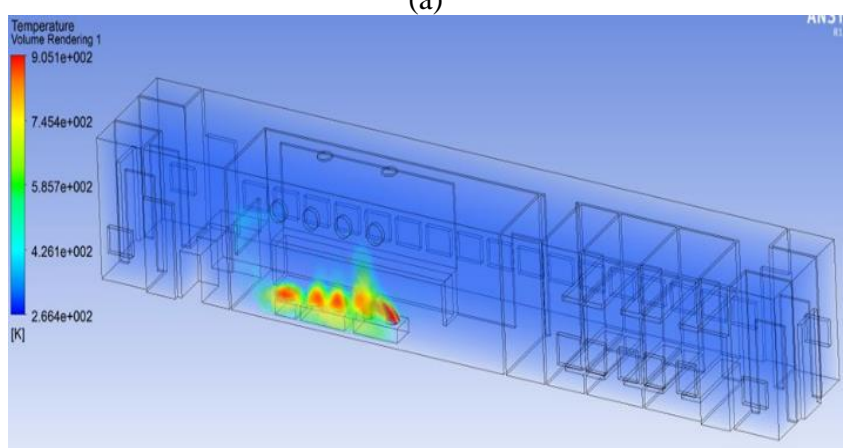

(b)

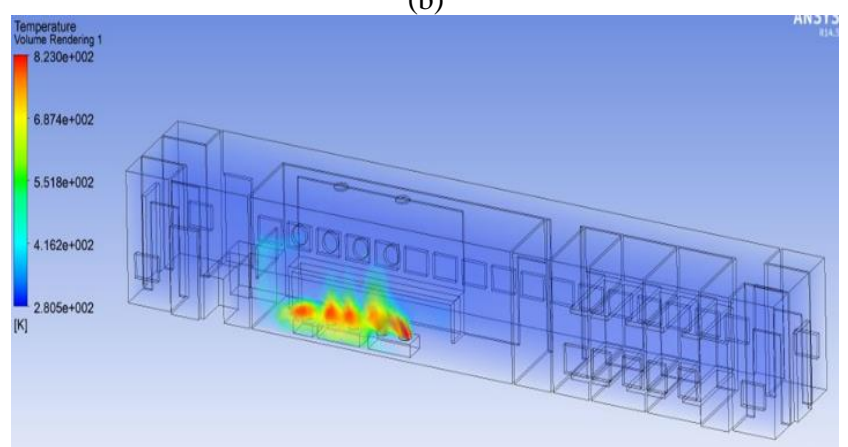

(c)

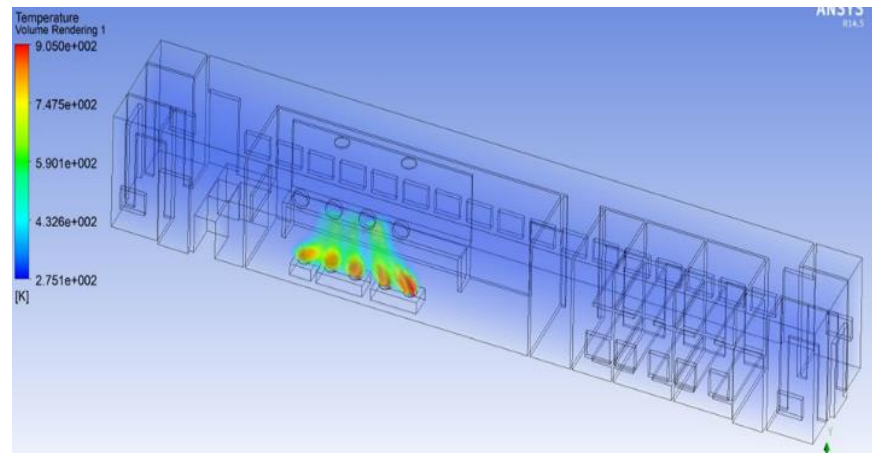

(d)

(i) Air temperature distribution profile

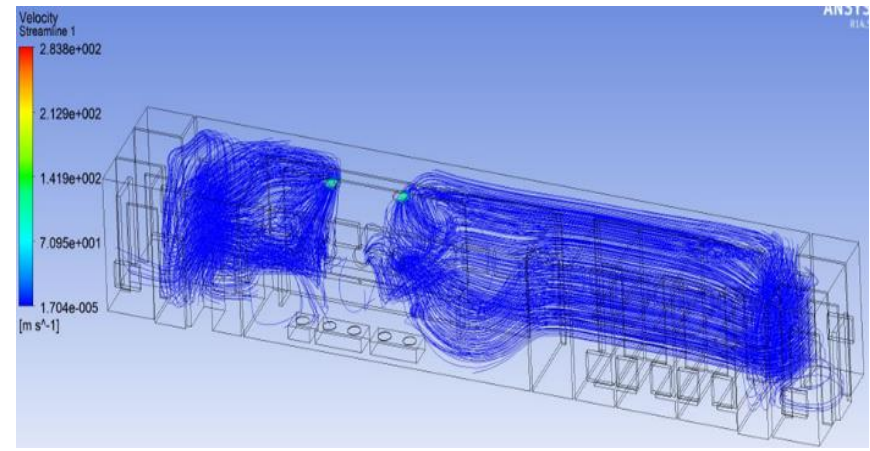

(a)

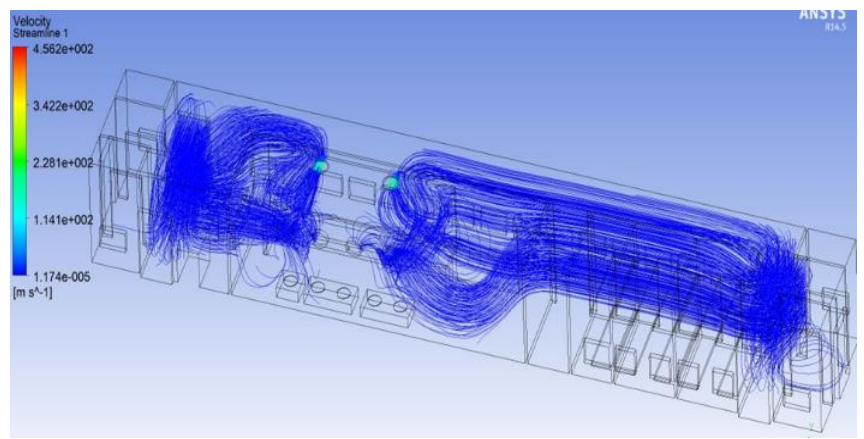

(b)

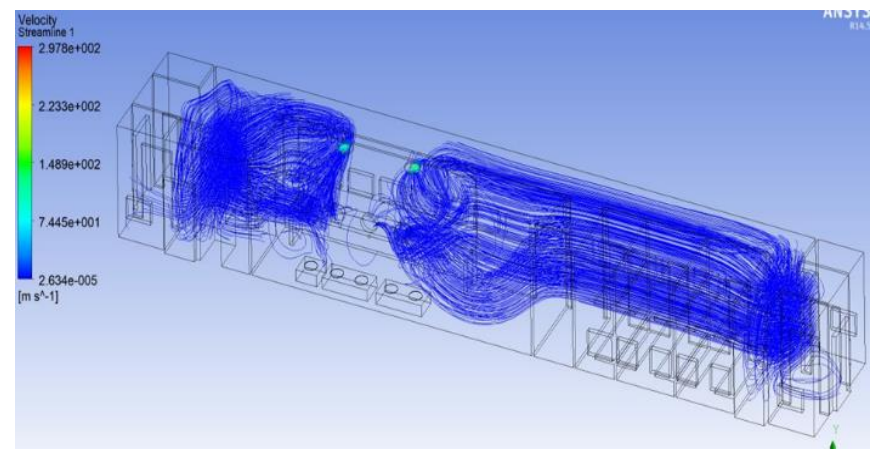

(c)

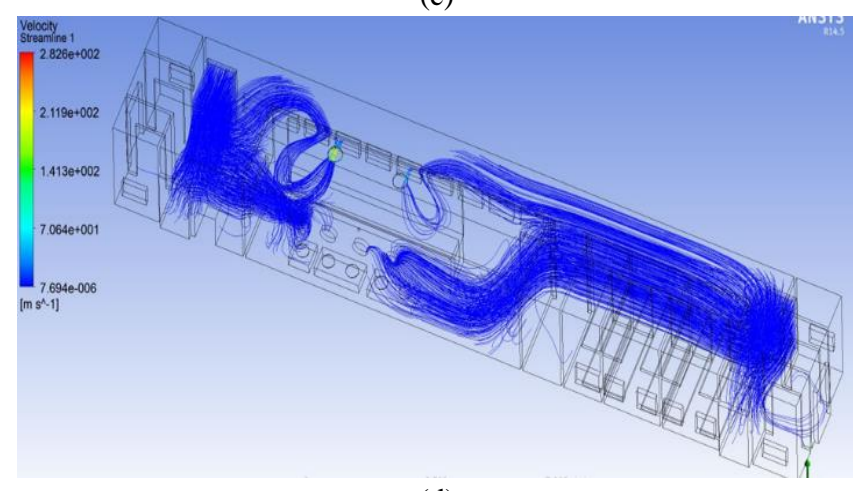

(d)

(ii) Velocity distribution profile

Figure 8. Case I, winter season (i) air temperature and (ii) velocity, distribution profile of CFD at various cooking period; (a) breakfast, (b) lunch, (c) snacks, and (d) dinner

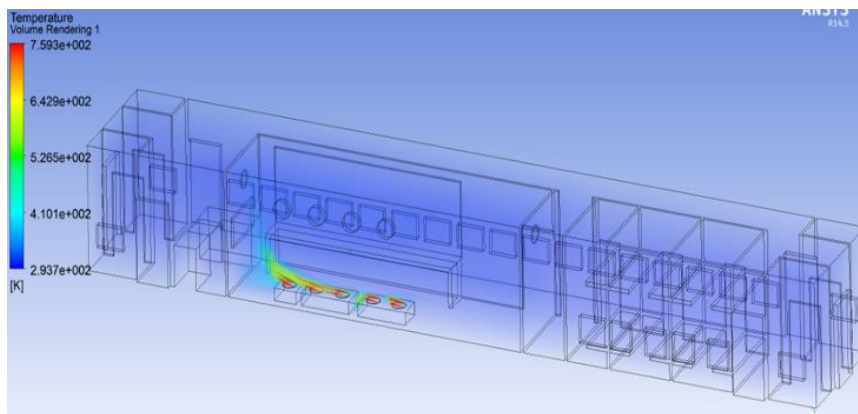

(a)

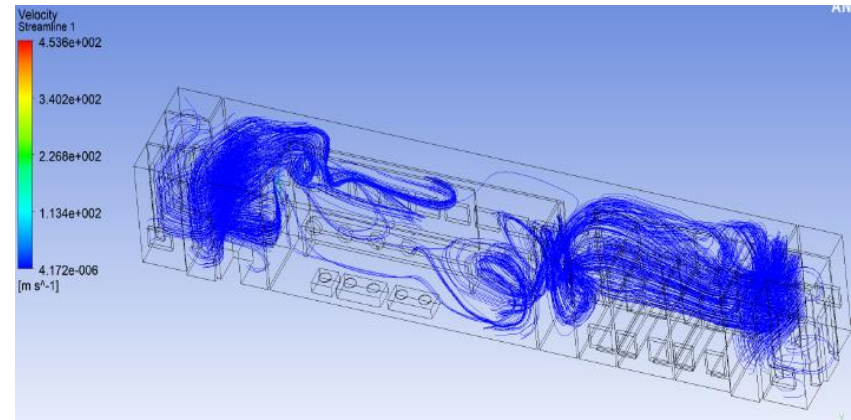

(a) 


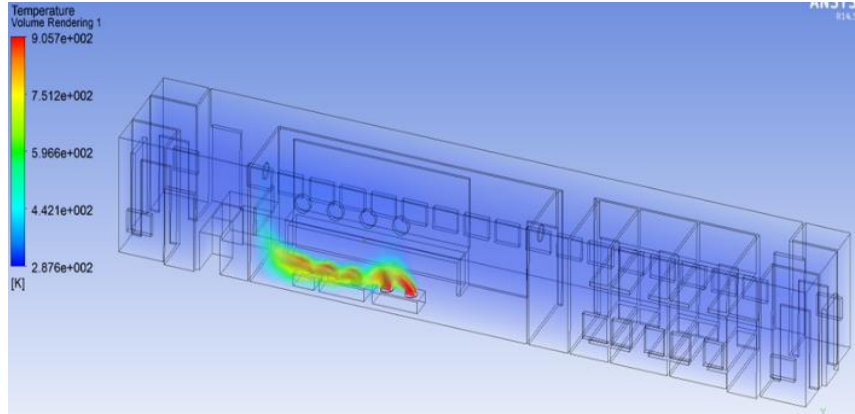

(b)

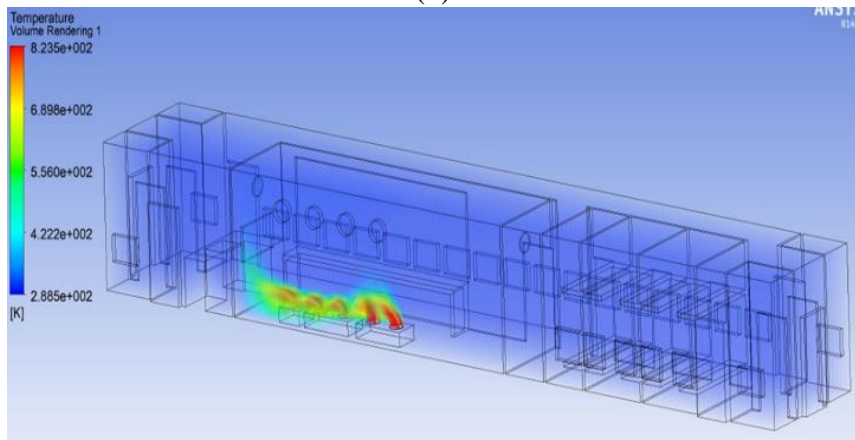

(c)

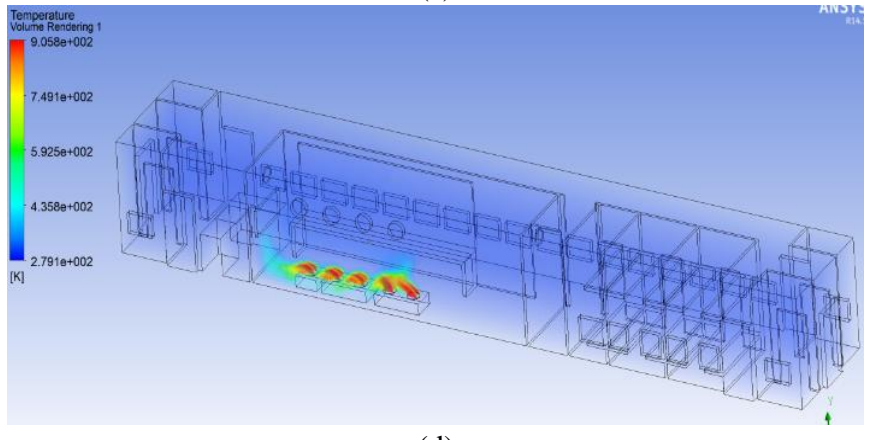

(d)

(i) Air temperature distribution profile

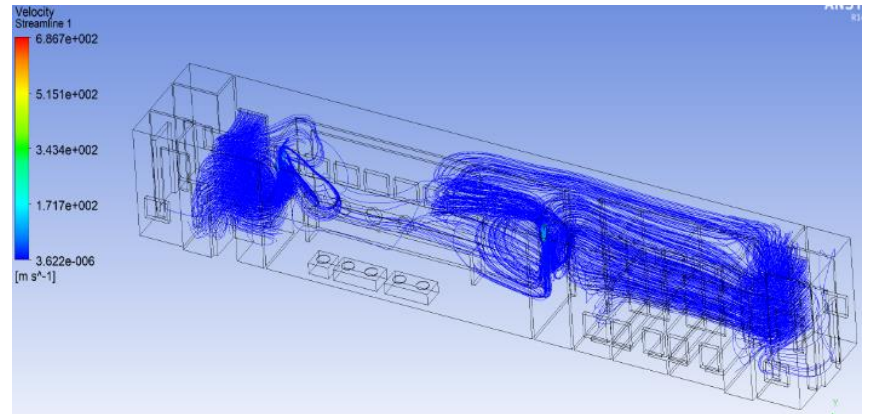

(b)
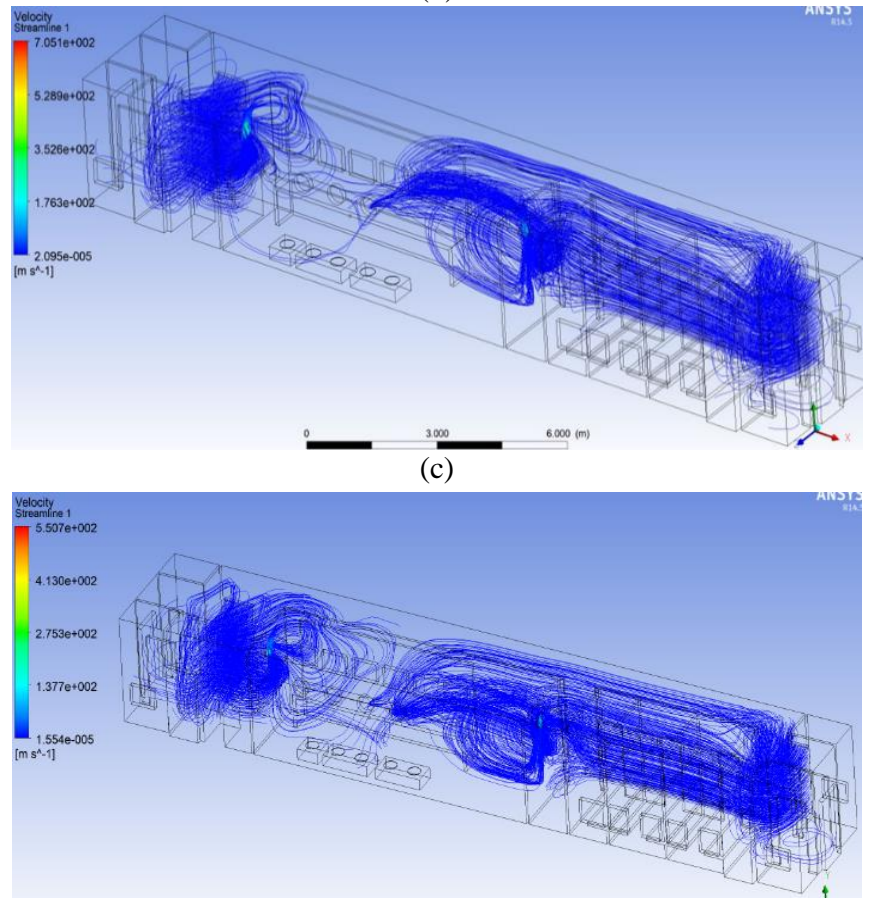

(d)

(ii) Velocity distribution profile

Figure 9. Case II, summer season (i) air temperature and (ii) velocity, distribution profile of CFD at various cooking period; (a) breakfast, (b) lunch, (c) snacks, and (d) dinner

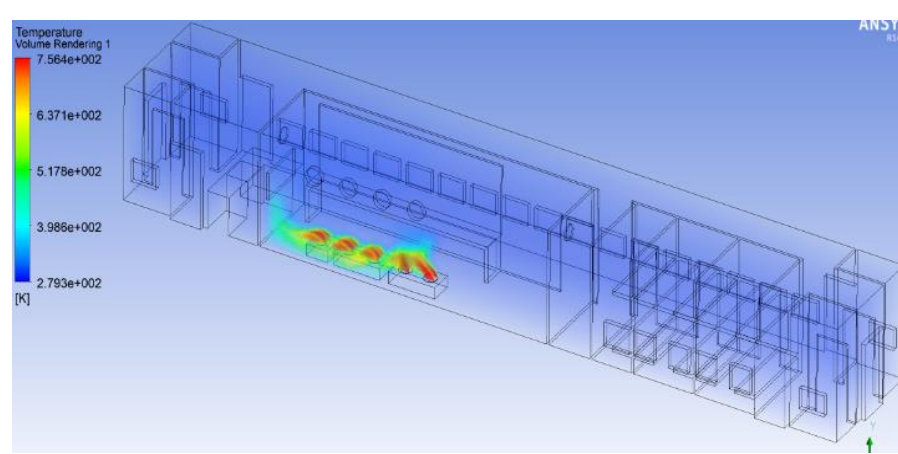

(a)
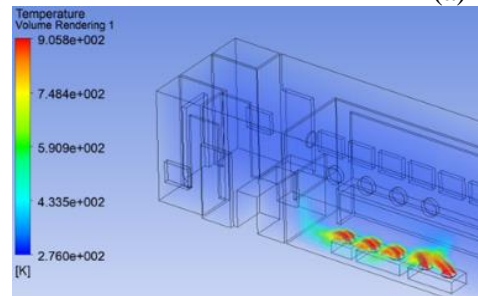

(b)

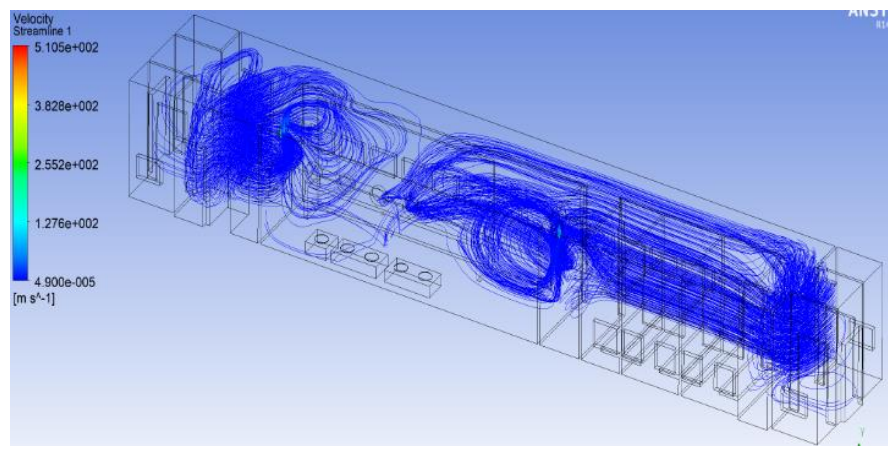

(a)

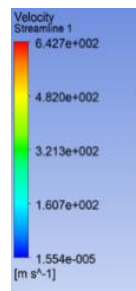

(b) 


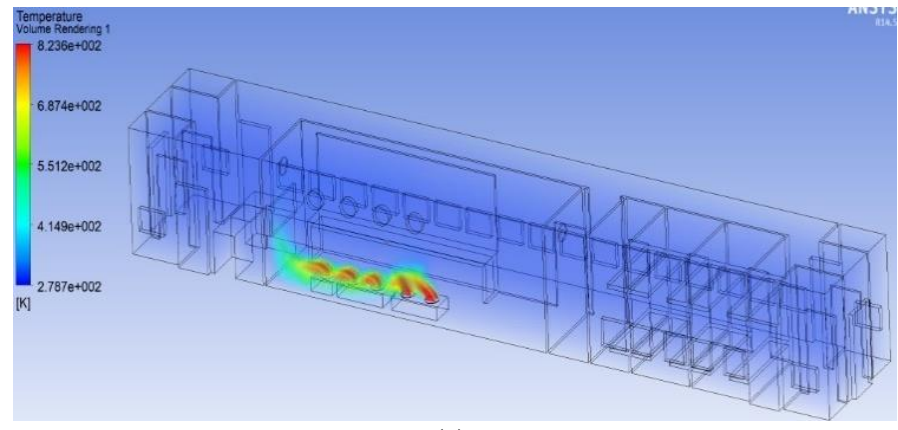

(c)

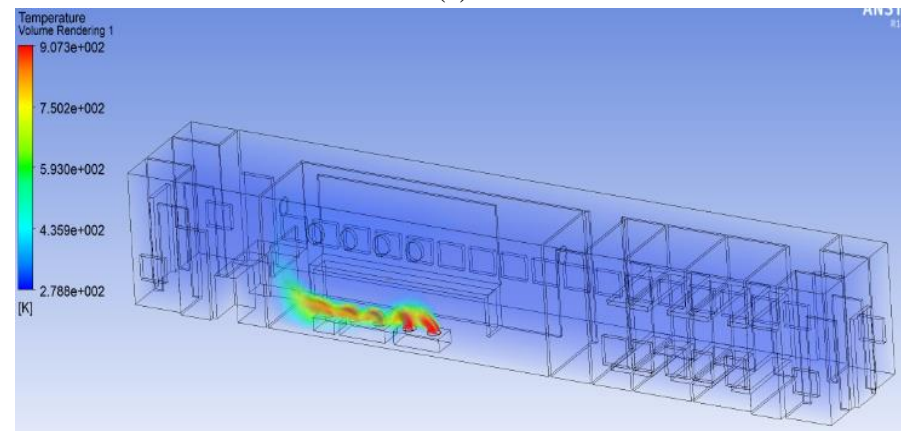

(d)

(i) Air temperature distribution profile

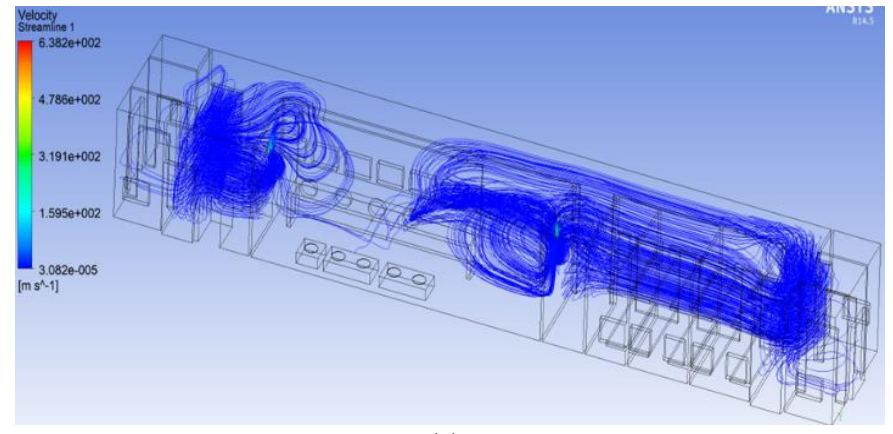

(c)

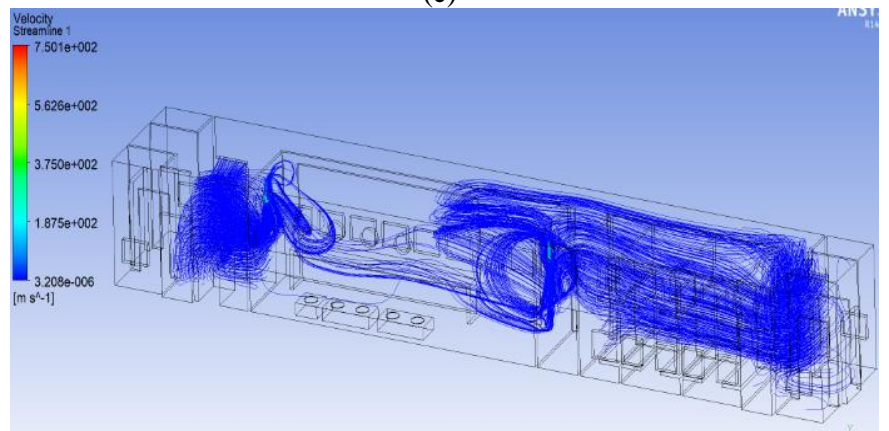

(d)

(ii) Velocity distribution profile

Figure 10. Case II, winter season (i) air temperature and (ii) velocity, distribution profile of CFD at various cooking period; (a) breakfast, (b) lunch, (c) snacks, and (d) dinner

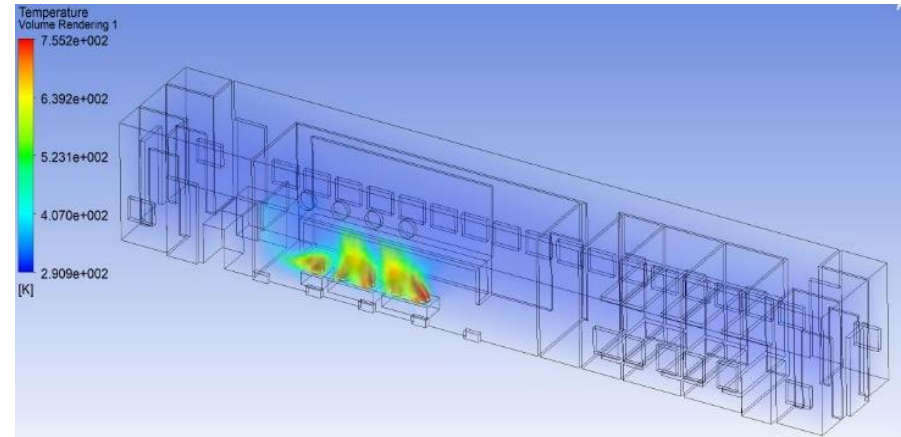

(a)

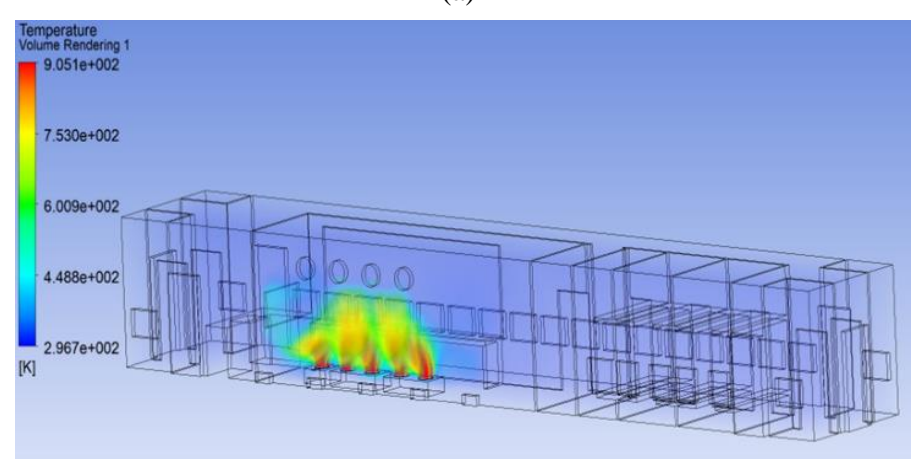

(b)

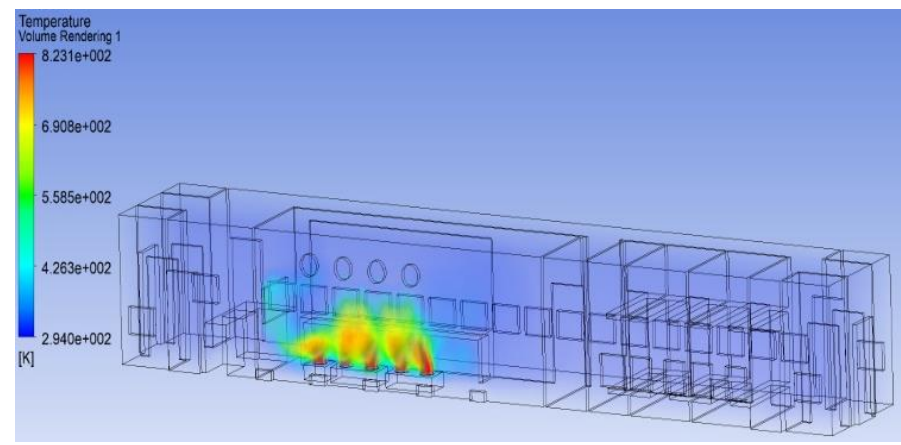

(c)

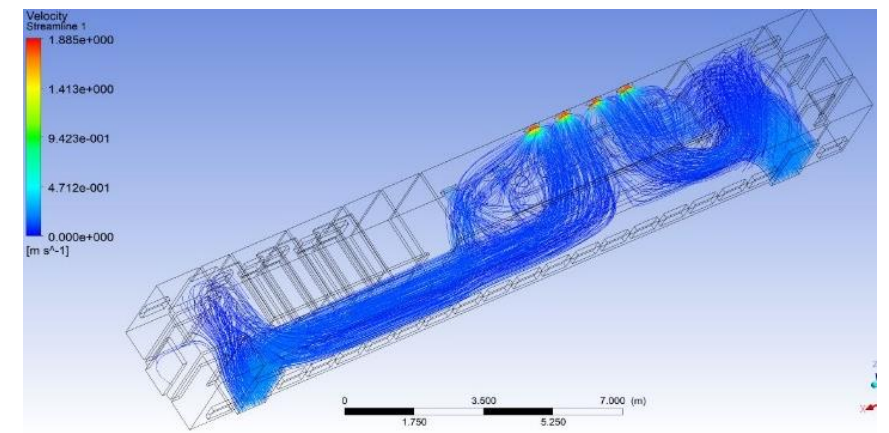

(a)

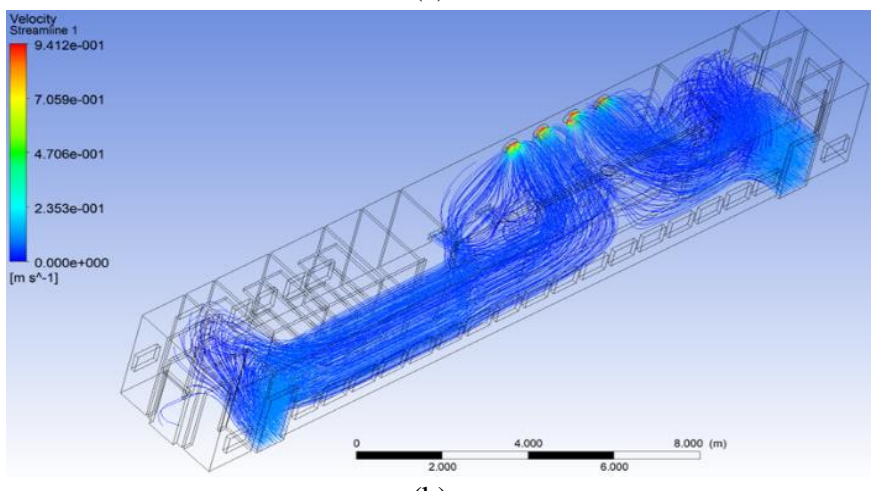

(b)

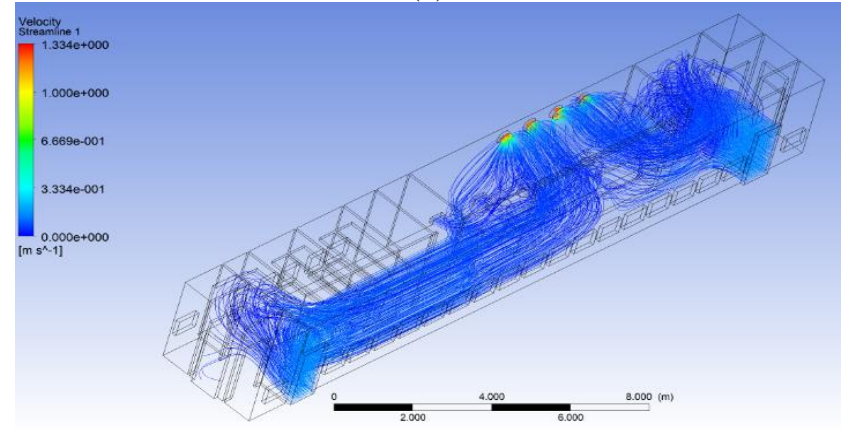

(c) 


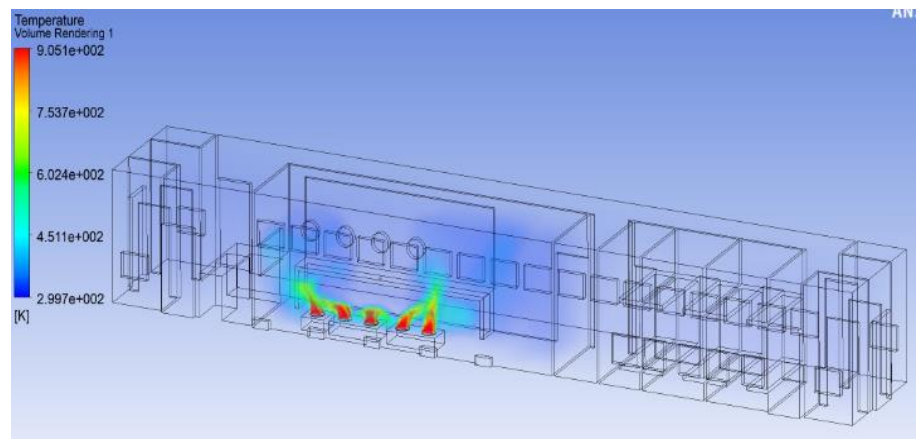

(d)

(i) Air temperature distribution profile

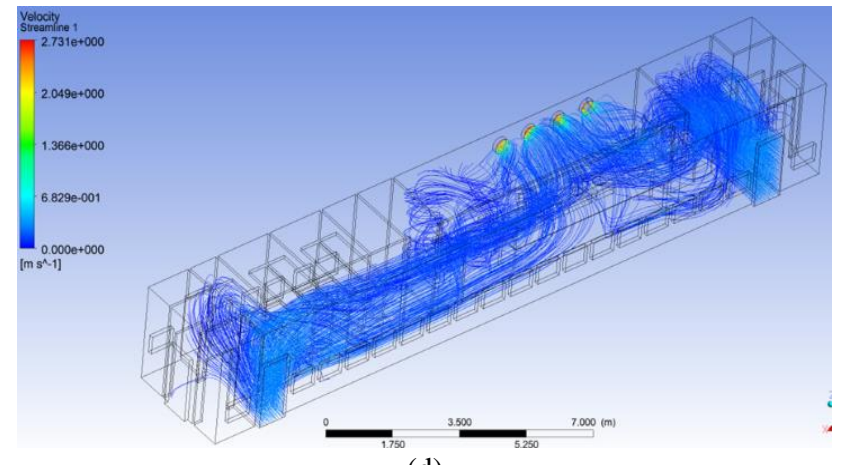

(d)

(ii) Velocity distribution profile

Figure 11. Case III, summer season (i) air temperature and (ii) velocity, distribution profile of CFD at various cooking period; (a) breakfast, (b) lunch, (c) snacks, and (d) dinner

Similarly, for case III, Figure 11 and Figure 12 show the summer and winter seasons air temperature and air velocity distribution profile at different cooking periods. In this case, during the summer season, the value of air temperature was found highest $\left(30.83^{\circ} \mathrm{C}\right)$ and lowest $\left(27.59^{\circ} \mathrm{C}\right)$ at lunch and breakfast periods respectively. Meanwhile, the air velocity speed was found to be highest at dinner $(0.06 \mathrm{~m} / \mathrm{s})$ and lowest

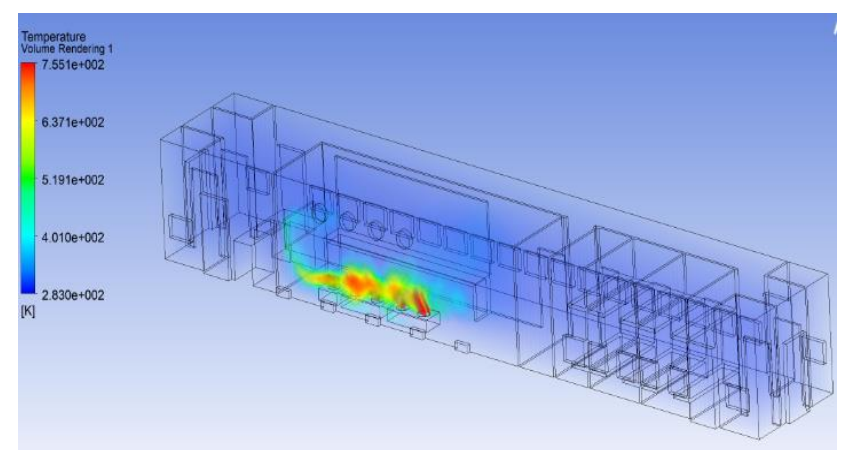

(a)

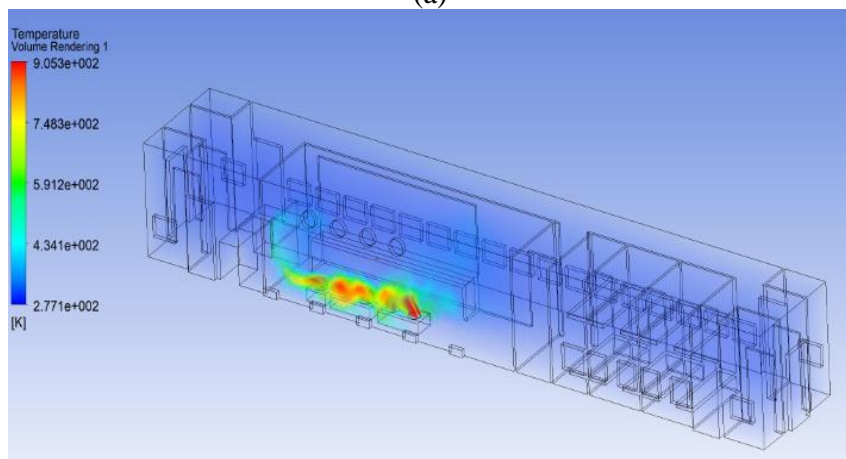

(b)

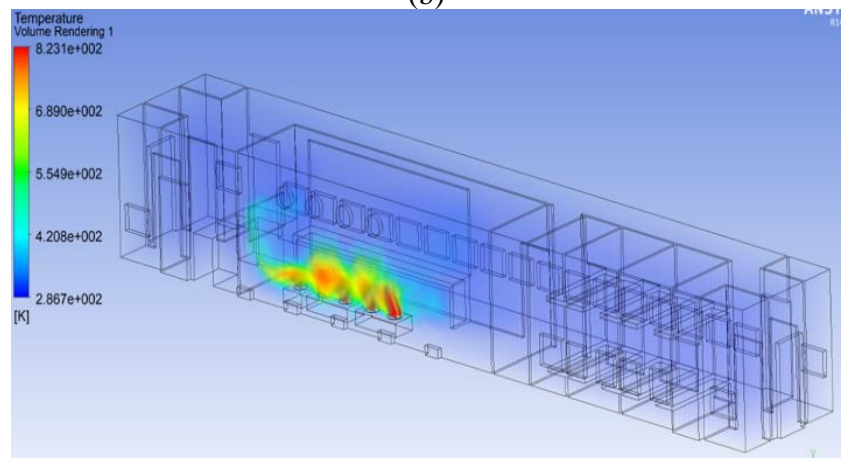

(c)
$(0.01 \mathrm{~m} / \mathrm{s})$ at the lunch periods. However, in the winter season, the value of air temperature has been found maximum $\left(26.61{ }^{\circ} \mathrm{C}\right)$ and minimum $\left(22.63^{\circ} \mathrm{C}\right)$ at lunch and breakfast periods respectively. Consistently, the movement of air velocity was rooted highest $(0.06 \mathrm{~m} / \mathrm{s})$ at lunch and lowest $(0.01 \mathrm{~m} / \mathrm{s})$ at dinner preparation time.

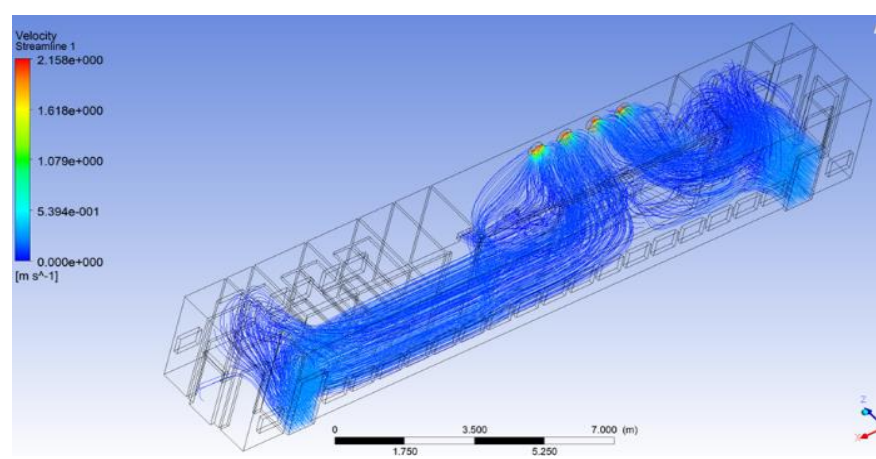

(a)
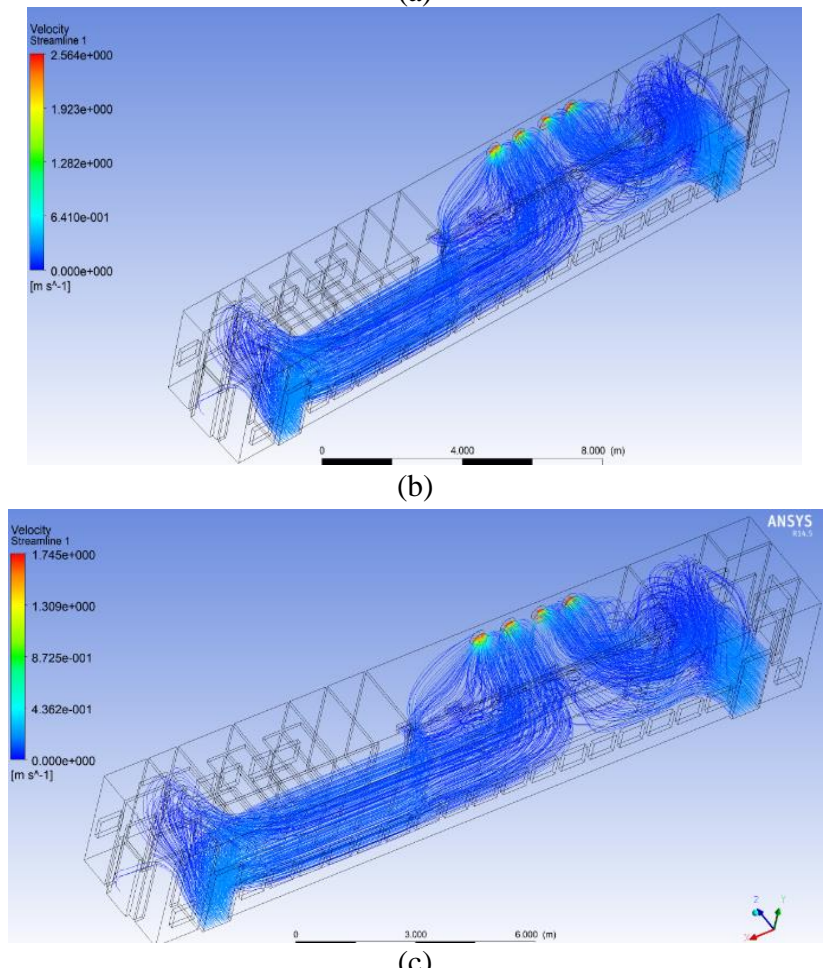

(c) 


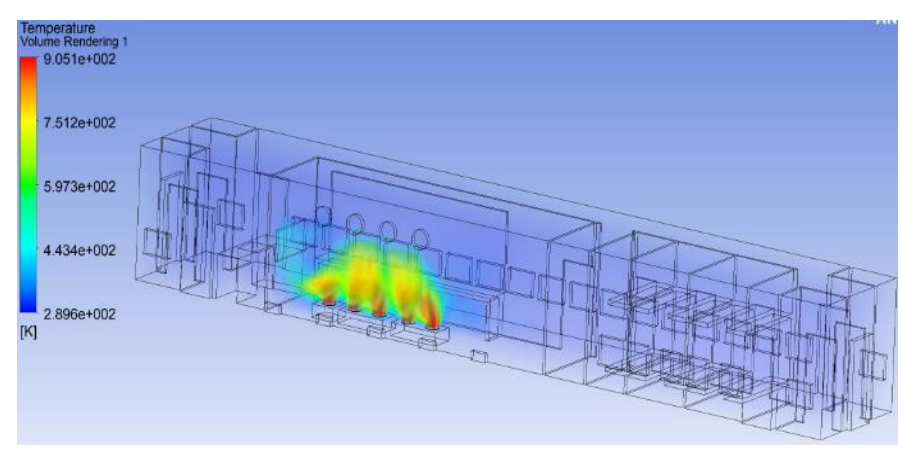

(d)

(i) Air temperature distribution profile

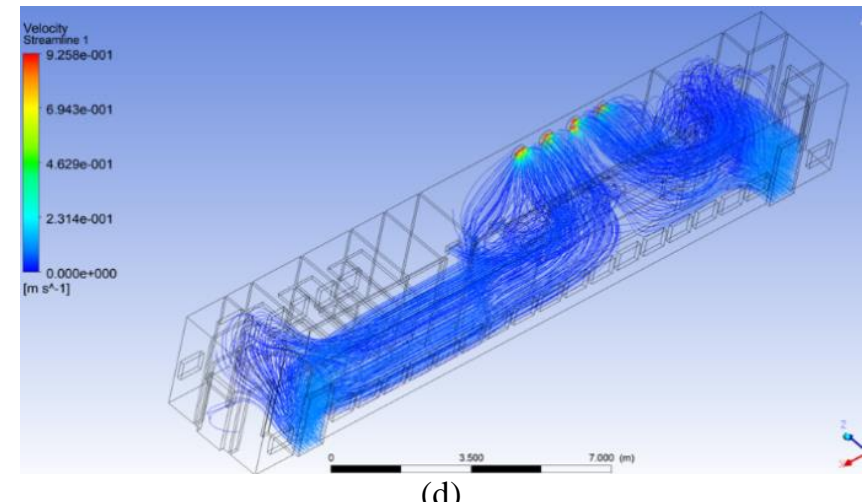

(d)

Figure 12. Case III, winter season (i) air temperature and (ii) velocity, distribution profile of CFD at various cooking period; (a) breakfast, (b) lunch, (c) snacks, and (d) dinner

Figure 13 and Figure 14 show the case IV, summer, and winter seasons air temperature and air velocity distribution profile at various cooking periods inside the kitchen of the railway pantry car. During the summer season, maximum $\left(31.07^{\circ} \mathrm{C}\right)$ and minimum $\left(27.8^{\circ} \mathrm{C}\right)$ air temperatures had been calculated over the lunch and breakfast periods. Likewise, the air velocity movement was found highest $(0.05 \mathrm{~m} / \mathrm{s})$ at dinner

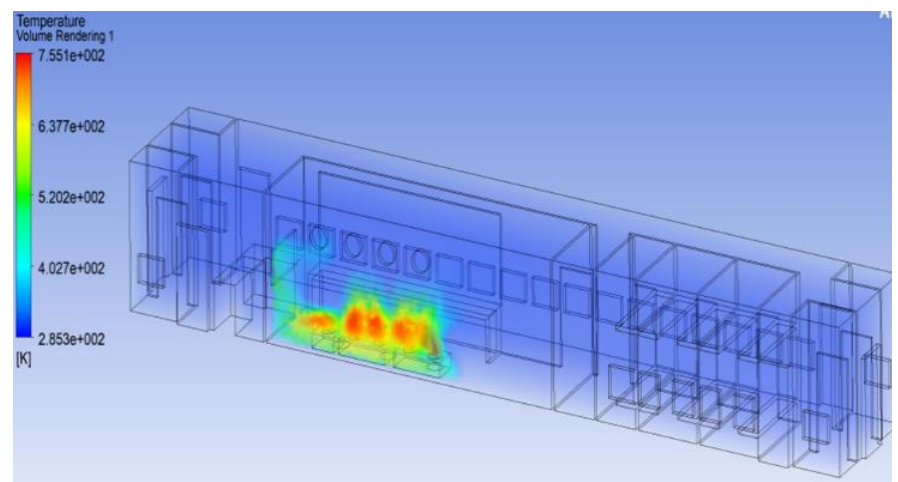

(a)

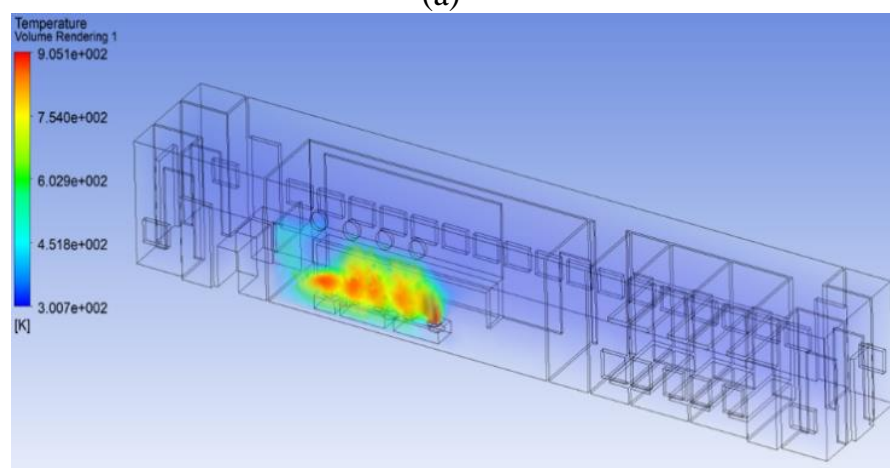

(b)

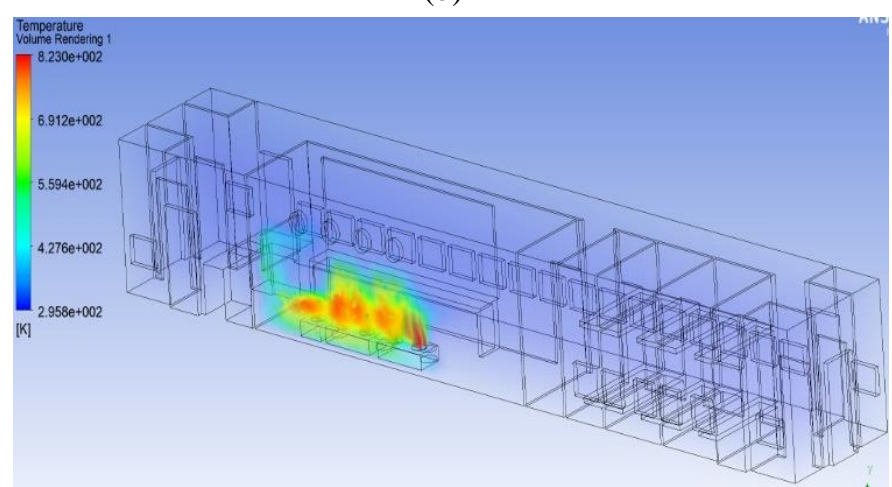

(c) and lowest $(0.01 \mathrm{~m} / \mathrm{s})$ at lunch preparation time. Similarly, during the winter season, the air temperatures were found maximum $\left(26.77^{\circ} \mathrm{C}\right)$ and minimum $\left(22.64^{\circ} \mathrm{C}\right)$ at lunch and breakfast. Whereas the movement of air velocity was noted highest $(0.05 \mathrm{~m} / \mathrm{s})$ and lowest $(0.01 \mathrm{~m} / \mathrm{s})$ respectively at lunch and dinner.

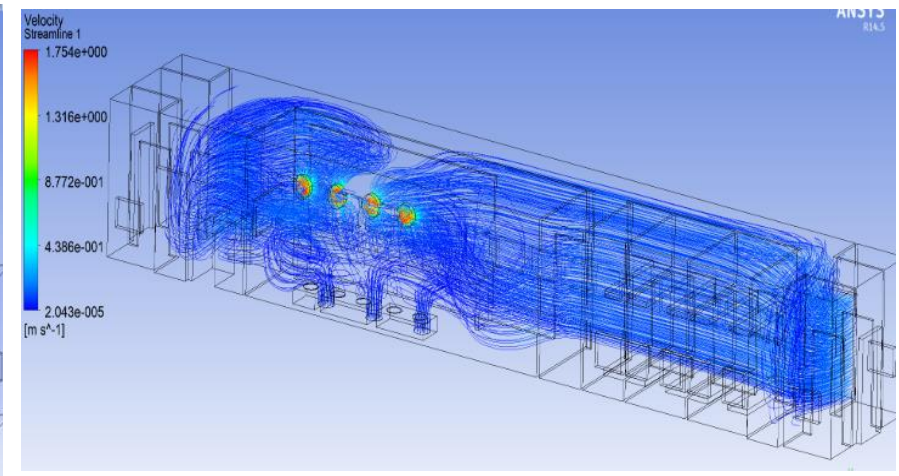

(a)

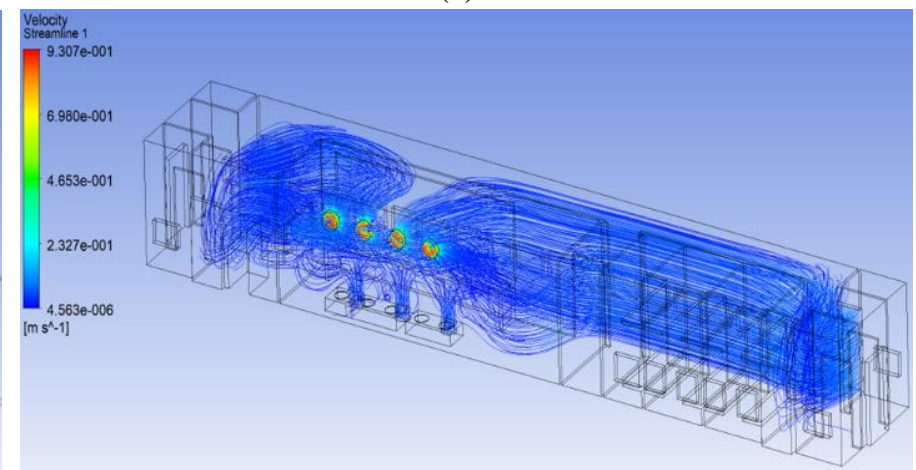

(b)

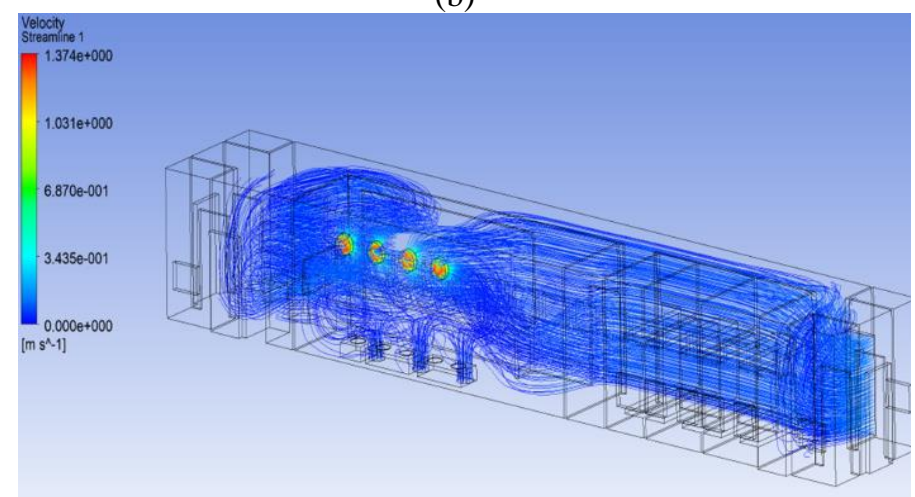

(c) 


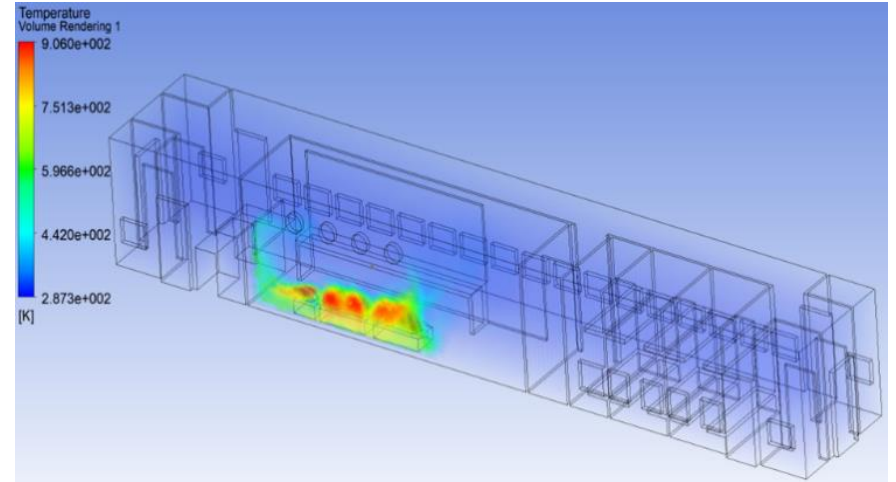

(d)

(i) Air temperature distribution profile

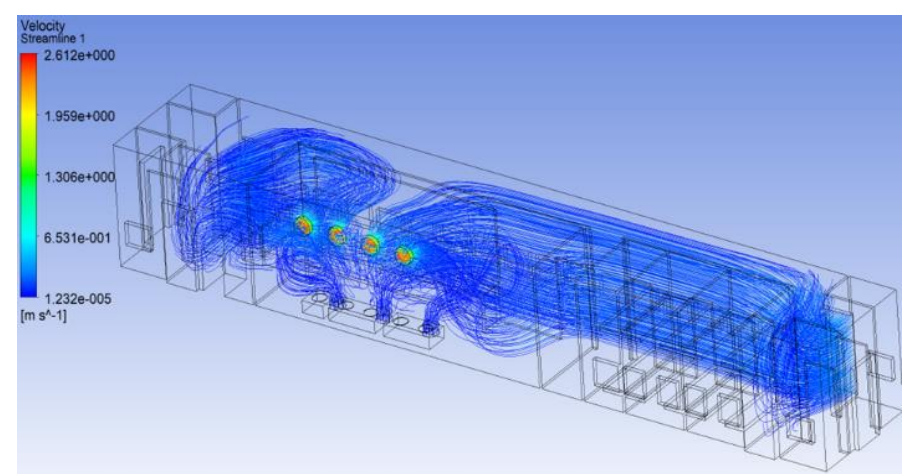

(d)

(ii) Velocity distribution profile

Figure 13. Case IV, summer season (i) air temperature and (ii) velocity, distribution profile of CFD at various cooking period; (a) breakfast, (b) lunch, (c) snacks, and (d) dinner

\subsection{Comparison of modified cases with existing case} based on the air temperature and air velocity

As the earlier thermal comfort study directed the predicted comfort air temperature limits of railway pantry car kitchen

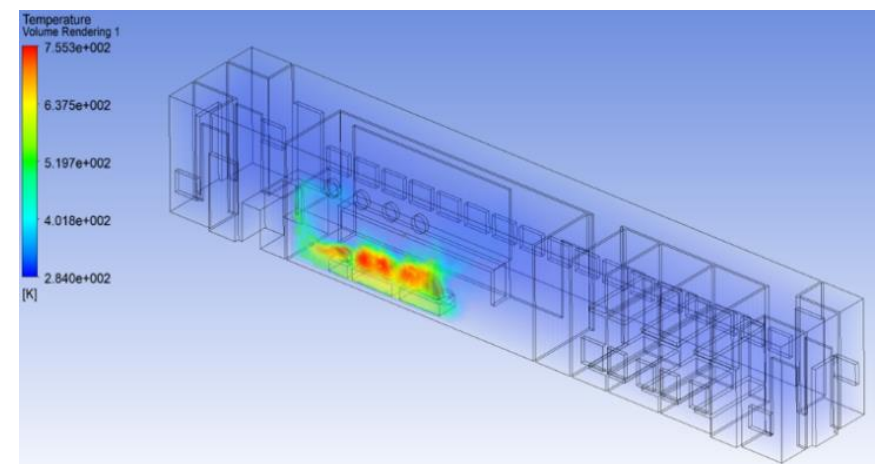

(a)

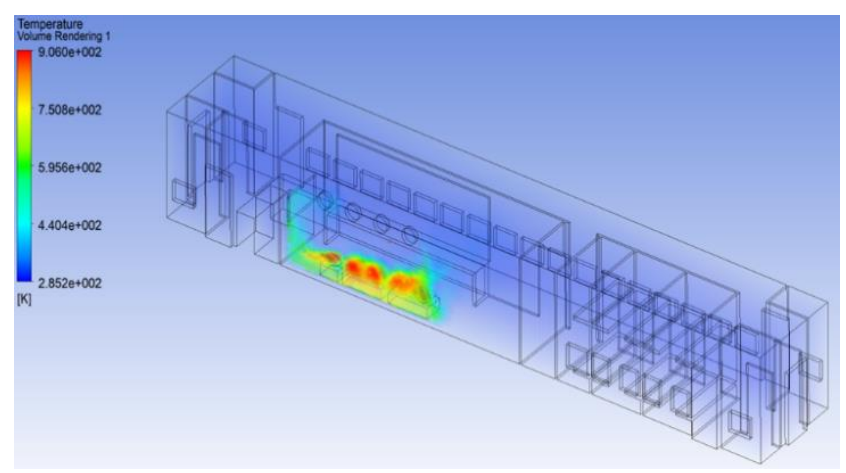

(b)

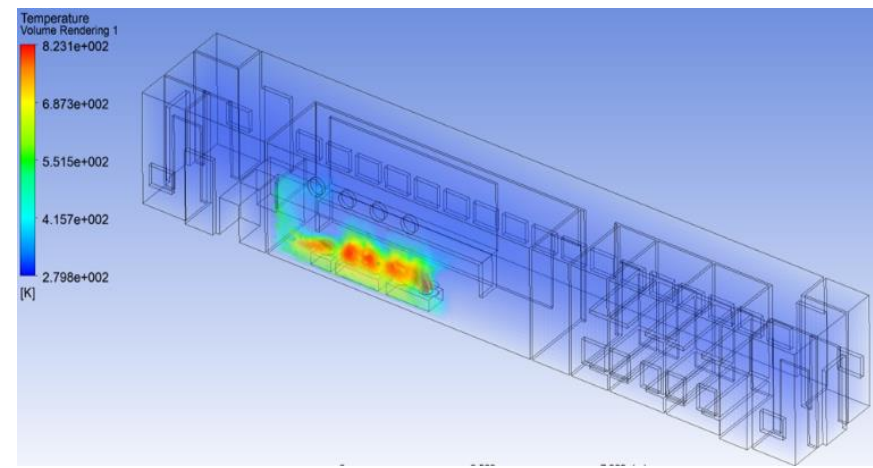

(c) workers were for the summer season $\left(18.50-27.80^{\circ} \mathrm{C}\right)$ and winter season $\left(17.80-25.50^{\circ} \mathrm{C}\right)$ [7]. In this study, we compared all modified pantry car models with existing cases based on the air supply system and air temperature upper limit.

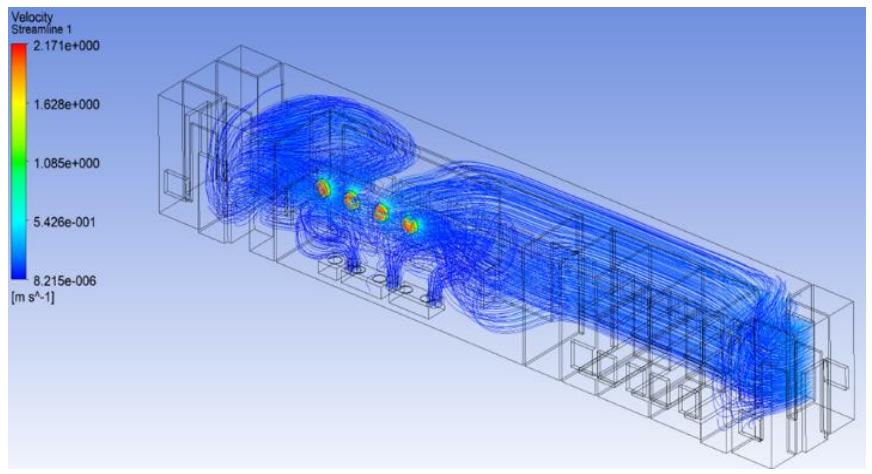

(a)

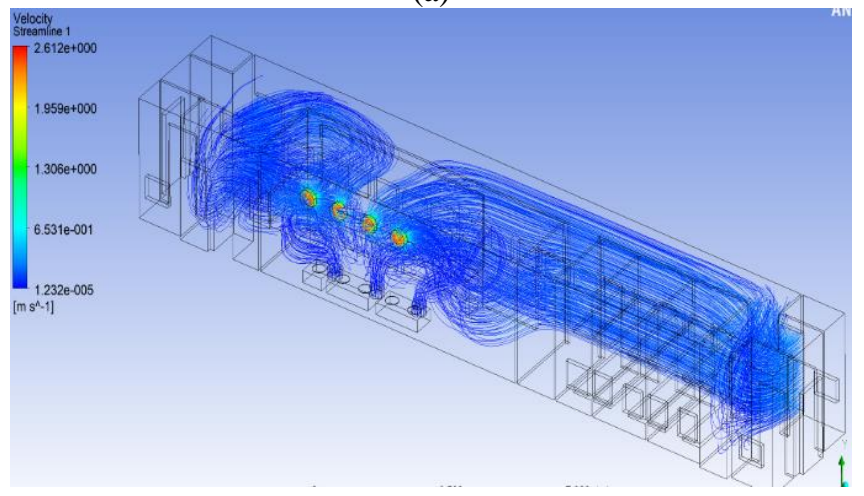

(b)

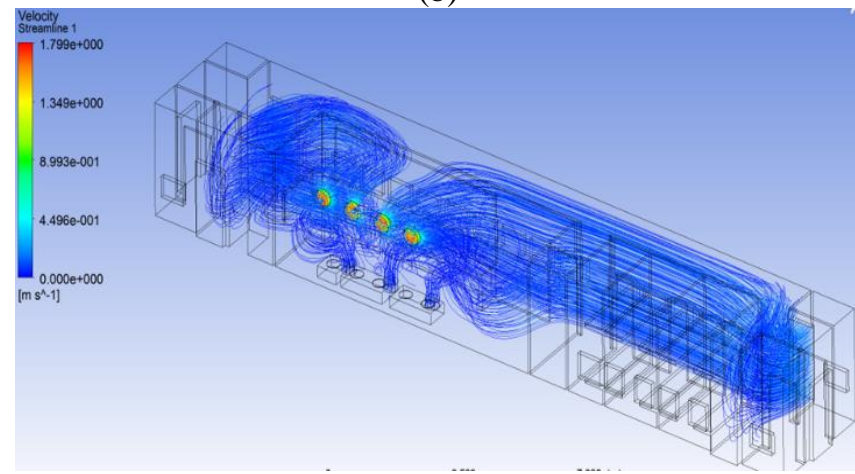

(c) 


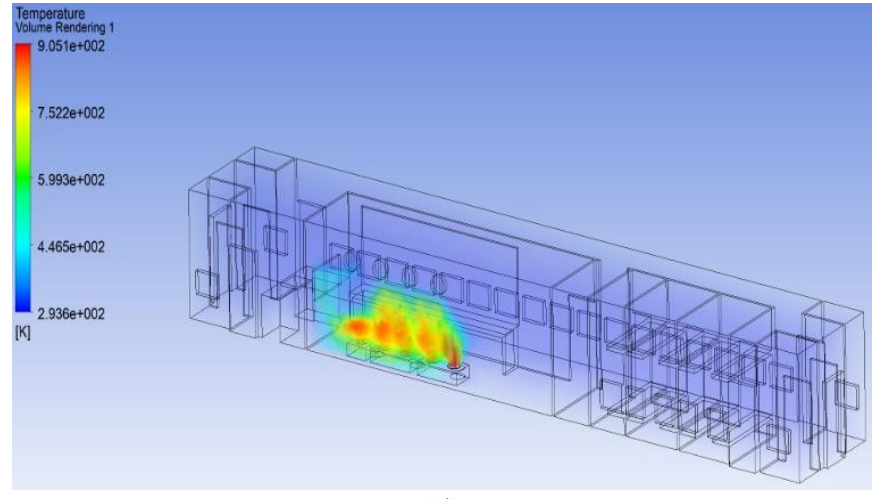

(d)

(i) Air temperature distribution profile

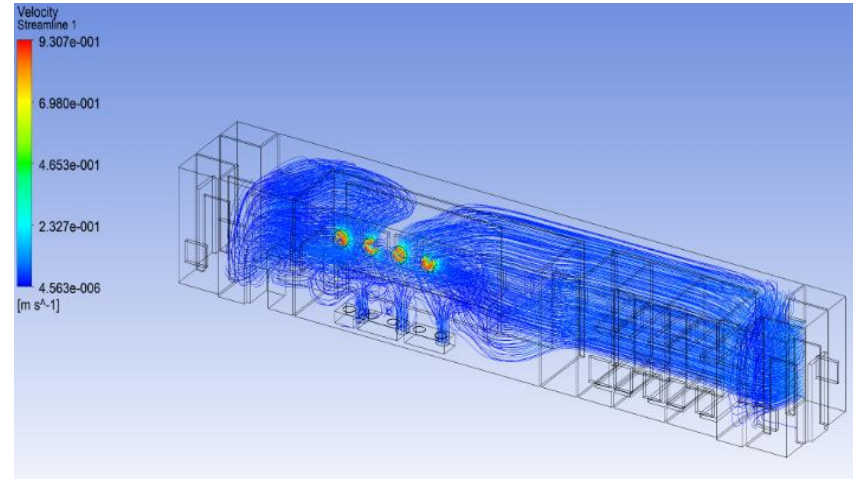

(d)

(ii) Velocity distribution profile

Figure 14. Case IV, winter season (i) air temperature and (ii) velocity, distribution profile of CFD at various cooking period; (a) breakfast, (b) lunch, (c) snacks, and (d) dinner

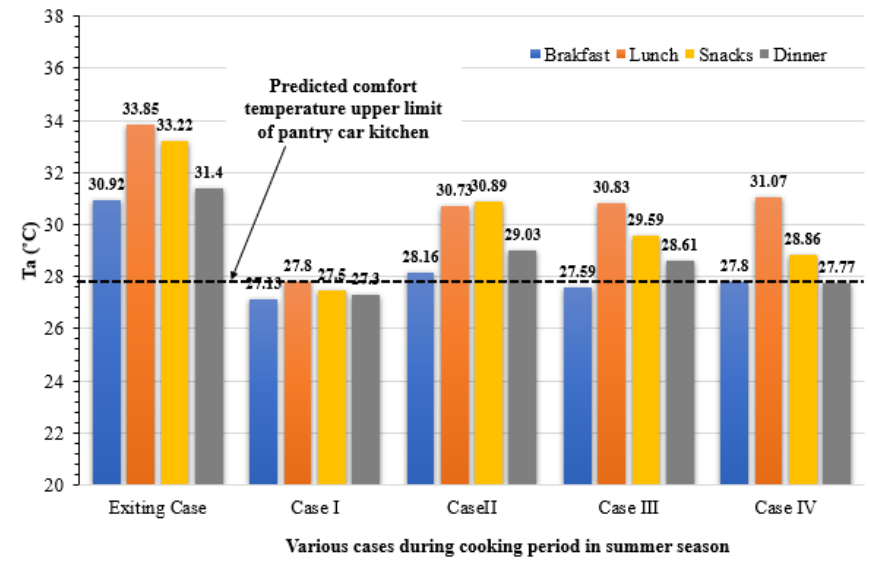

(a) Summer season

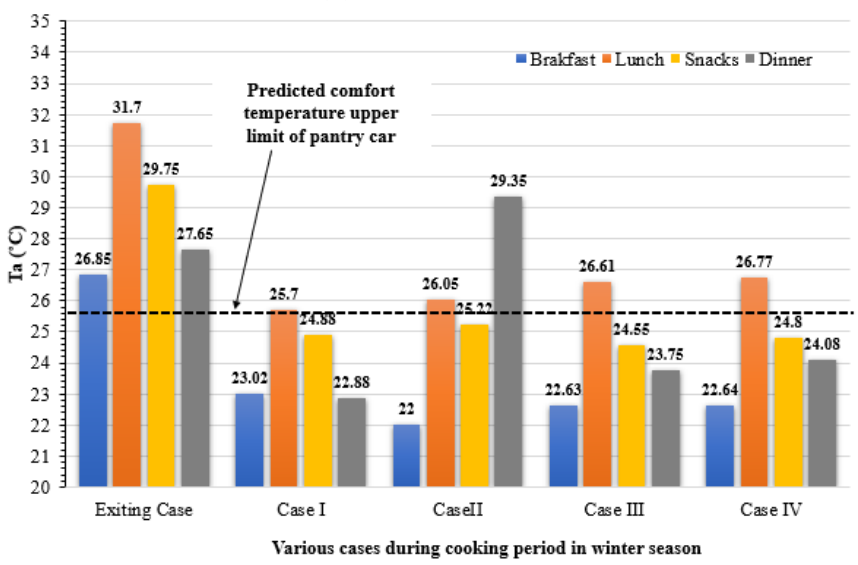

(b) Winter season

Figure 15. Air temperature comparison of the existing case with all modified cases during (a) summer, and (b) winter season

Figure 15 (a) shows the comparison between modified and existing cases of pantry car kitchens based on the air temperature during the summer season. The graphical result indicates case I, coming within the recommended comfort temperature range as compared to the other modified cases because it keeps all cooking periods under the comfort temperature zone. It can be observed that in case I, entire cooking periods like breakfast, lunch, snacks, dinner the temperature has dropped $3.79^{\circ} \mathrm{C}, 6.05^{\circ} \mathrm{C}, 5.72^{\circ} \mathrm{C}, 4.1^{\circ} \mathrm{C}$ respectively as compare to the existing case. However, in other modified cases also the temperature has dropped as corresponding to the existing model but in most of the cooking periods, the temperature has gone beyond the recommended comfort temperature limit.

Similarly, Figure 15 (b) demonstrates the comparison between modified and existing cases of pantry car kitchens based on the air temperature during the winter season. During the entire winter season also the graphical results indicate the case-I is better as compared to other modified pantry car models at the various cooking periods and It complies with the recommended limit of comfort temperature. As comparing case-I with the existing case model the temperature has decreased $3.83^{\circ} \mathrm{C}, 6^{\circ} \mathrm{C}, 4.87^{\circ} \mathrm{C}$, and $4.77^{\circ} \mathrm{C}$ respectively at breakfast, lunch, snacks, and dinner time. In the winter season too, all modified cases temperature has been decreased as corresponding to the existing model but in a few cooking periods, the temperature has gone beyond the upper limit of the comfort temperature.

Figure 16 (a) shows the comparative graph of air velocity between existing and modified cases at different cooking periods inside the kitchen of the pantry car. From the graphical results, during the entire summer season, it can be observed that case I have better air velocity movement as compared to the modified cases. While the case I compared with the existing case model the values of air velocity have increased at all cooking periods; breakfast $(0.13 \mathrm{~m} / \mathrm{s})$, lunch $(0.13 \mathrm{~m} / \mathrm{s})$, snacks $(0.13 \mathrm{~m} / \mathrm{s})$, and dinner $(0.14 \mathrm{~m} / \mathrm{s})$. However, there are no huge changes in air movement in case III and case IV modified model corresponding to the current model.

Similarly, for the winter season, the comparative graph of air velocity between existing and modified cases at different cooking periods is illustrated in Figure 16 (b). During the winter season, it has also been observed that Case I has maximum air velocity. However, apart from case I the maximum air velocity has been found in case II at overall cooking periods. While in case III and case IV, no change has been seen in the movement of air velocity. The movement of air velocity has increased at cooking period; breakfast $(0.19 \mathrm{~m} / \mathrm{s})$, lunch $(0.06 \mathrm{~m} / \mathrm{s})$, snacks $(0.1 \mathrm{~m} / \mathrm{s})$, and dinner $(0.13 \mathrm{~m} / \mathrm{s})$, respectively in case I as compared to the existing case.

According to the ASHRAE standard-55 [11], the recommended values of air velocity for the summer and winter seasons should be $(<0.25 \mathrm{~m} / \mathrm{s})$, and $(<0.15 \mathrm{~m} / \mathrm{s})$, respectively $[44,45]$. In the present investigation, these findings had considerable compatibility in both air temperature and air 
velocity which is an important factor for thermal comfort. This has been brought to a considerable extent in the recommended range which will help increase the thermal comfort in the kitchen of the railway pantry car.

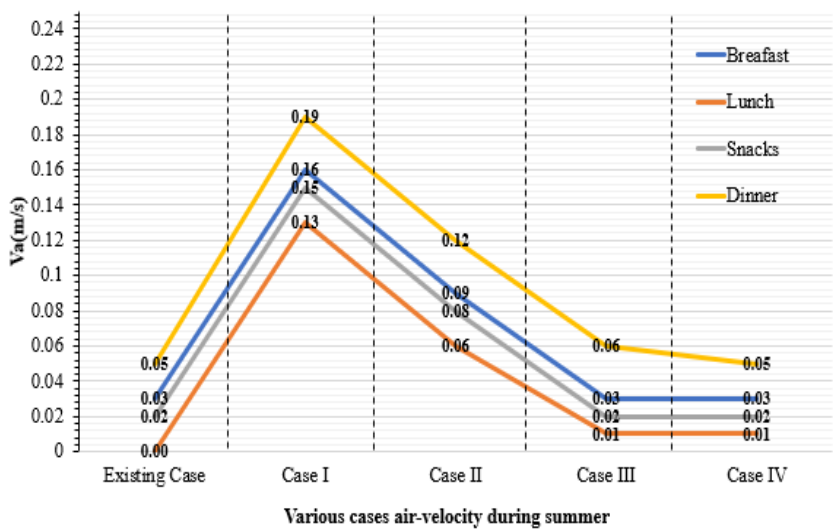

(a) Summer season

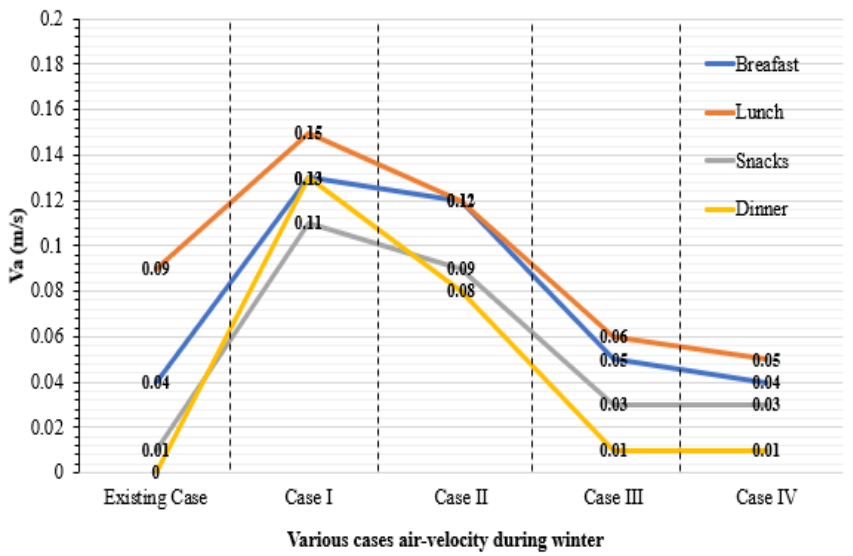

(b) Winter season

Figure 16. Average air velocity rate comparison of the existing case with all modified cases during (a) summer, and (b) winter season

\subsection{Thermal comfort estimation}

The SET index has been used to predict "thermal comfort conditions" in the present study, which identifies the position of the "thermal sensation range" in applied ventilation systems. In this also all the modified cases model have been compared to the existing case model based on the estimate of the SET index.

A comparison of the current case with all the modified cases during the summer season according to the SET illation is depicted in Figure 17 (a). Entire summer season the calculated results of SET values indicate the case-I has a better comfort model as compare to the other cases. In case-I, the SET temperature range $\left(28.6-30^{\circ} \mathrm{C}\right)$ was found between all cooking periods which dictates a comfortable thermal sensation value. Similarly in case-II, the SET range $\left(30.4-31.8^{\circ} \mathrm{C}\right)$ was observed between the whole cooking periods with a "warm" thermal sensation value. However, in case-III only breakfast timing has a comfortable thermal sensation with $29.8^{\circ} \mathrm{C}$ SET and other cooking periods were a warm thermal sensation. In the case-IV, the total duration of cooking was found within the SET range $\left(30-33.2^{\circ} \mathrm{C}\right)$ with a warm thermal sensation. Accordingly, in the existing case model, the range of all cooking period SETs has been calculated at $37-39.8^{\circ} \mathrm{C}$ with a "very hot" thermal sensation that does not comply with human thermal comfort. While comparing the existing case model with the case-I model the SET temperature has reduced at all cooking period; breakfast $\left(8.1^{\circ} \mathrm{C}\right)$, lunch $\left(9.8^{\circ} \mathrm{C}\right)$, snacks $\left(9.8^{\circ} \mathrm{C}\right)$, and dinner $\left(9.8^{\circ} \mathrm{C}\right)$. Other modified cases also had lower SET values than the existing case model but the "warm" thermal sensation was found, which is slightly uncomfortable.

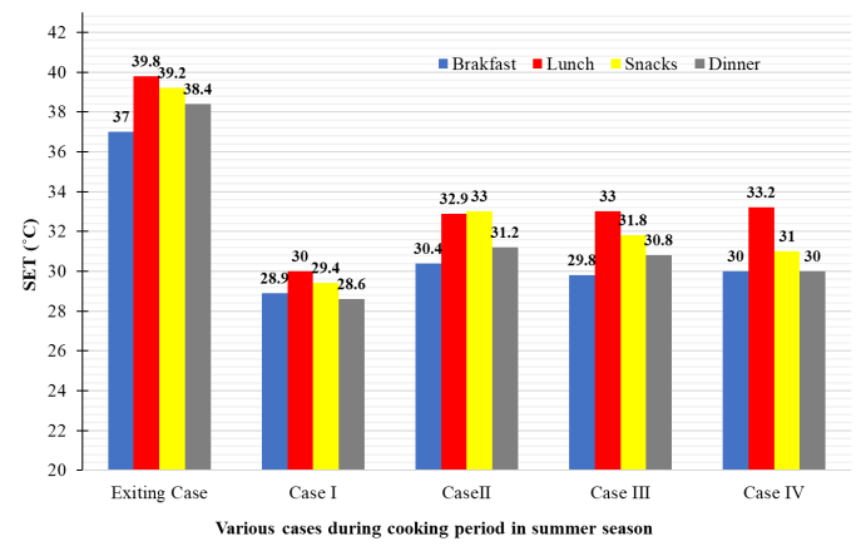

(a) Summer season

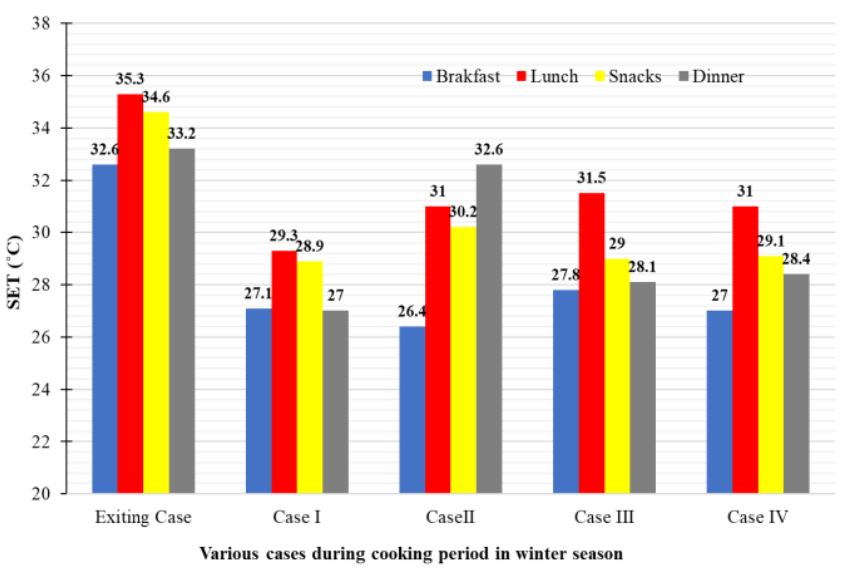

(b) Winter season

Figure 17. SET thermal sensation comparison of the existing case with all modified cases during (a) summer, and (b) winter season

Similarly, Figure 17 (b) shows the comparison of SET values between existing and modified case models during the winter season. As a result of the SET index values, during the winter season also the case-I model has the preferable concept for the enhancement of thermal comfort. Because in case-I, the SET value $\left(27-29.3^{\circ} \mathrm{C}\right)$ was found with a "comfortable" thermal sensation throughout the cooking period. Correspondingly, case-II found SET values $\left(30.2-32.6^{\circ} \mathrm{C}\right)$ with a "warm" thermal sensation in all cooking periods except for breakfast time only. In the case of III, a "comfortable" thermal sensation was observed in the breakfast and dinner preparation periods, while in other periods "warm" thermal sensation was observed. However, in case-IV, only lunch preparation time was found to be SET $\left(31^{\circ} \mathrm{C}\right)$ with a "warm" thermal sensation, while the rest of the other cooking periods had a "comfortable" thermal sensation with the SET value range $\left(27-29.1^{\circ} \mathrm{C}\right)$. Throughout the winter season, the temperature of SET has significantly reduced in case-I at each cooking period; breakfast $\left(5.5^{\circ} \mathrm{C}\right)$, lunch $\left(6.2^{\circ} \mathrm{C}\right)$, snacks $\left(5.7^{\circ} \mathrm{C}\right)$, and dinner $\left(6.2^{\circ} \mathrm{C}\right)$ respectively as compared to the existing case. The simulation result of the existing case has directed the thermal sensation range "warm to hot", which 
indicates a discomfort thermal environment for occupants. Even the other modified case's values of the SET have also come down but this is inconvenient because the range of thermal sensation "warm" has been found which is a bit uncomfortable for the workers.

Explication of the above results directed that installing four exhaust fans with a diameter of $450 \mathrm{~mm}$ in front of the kitchen wall and two carriage fans with a diameter of $400 \mathrm{~mm}$ on the roof would increase the thermal comfort in the kitchen environment of the Indian railway non-airconditioned pantry car. These interventions can be applied abruptly because it is low power consumption as well as easy concepts, and its maintenance costs are also low.

\section{CONCLUSIONS}

Present study examines the thermal comfort conditions inside the kitchen of the railway pantry car during the "summer and winter season" at different cooking periods followed by comparing the existing model with the modified pantry design model. In this study, field measurements were performed whereby parametric data was obtained to calculate the SET index identifying thermal comfort. While a CFD approach was used to compare the existing case with modified case models at working conditions. Four different modified case models conceptualized based on the comfort temperature range, air velocity, and simultaneously SET index were investigated, where one case was found suitable for the thermal environment of the pantry car.

In the analysis, it was found that the existing case model is outside the recommended range of the SET index which is not favorable for occupants. Also, declared that "case-I" significantly improved air velocity and reduced indoor temperature which helps to enhance thermal comfort by installing "four exhaust fans with a diameter of $450 \mathrm{~mm}$ " on the front wall of the kitchen and "two carriage fans with a diameter of $400 \mathrm{~mm}$ " on the roof sequentially. As well as the results of the parametric study "case-I" was observed to have a SET range between $\left(28.6-30^{\circ} \mathrm{C}\right)$ with comfortable thermal sensation over the cooking period, which is better for human occupancy. It is an important interpreter for the improvement of thermal comfort conditions and saves energy consumption in non-air-conditioned pantry car kitchens in Indian Railways.

\section{REFERENCES}

[1] Rahmillah, F.I., Tumanggor, A.H.U., Sari, A.D. (2017). The analysis of thermal comfort in kitchen. IOP Conference Series: Materials Science and Engineering, 215(1): $\quad 012033$. https://doi.org/10.1088/1757$899 X / 215 / 1 / 012033$

[2] Livchak, A., Schrock, D., Sun, Z. (2005). The effect ofsupply air systems on kitchen thermal environment. ASHRAE Transactions, 111(1): 748-754.

[3] Ravindra, K., Agarwal, N., Kaur-Sidhu, M., Mor, S. (2019). Appraisal of thermal comfort in rural household kitchens of Punjab, India and adaptation strategies for better health. Environment International, 124: 431-440. https://doi.org/10.1016/j.envint.2018.12.059

[4] Alam, M.S., Arunachalam, M., Salve, U.R. (2019). A pilot study on thermal comfort in Indian Railway pantry car chefs. Journal of Physics: Conference Series, 1240(1):
012033

https://doi.org/10.1088/1742-

6596/1240/1/012033

[5] Pethkar, G., Jadhav, S., Dhumal, P., Bhosale, P., Ahir, P.R. (2015). Automated pantry car system in India using RF module and GSM technology. International Journal of Advanced Research in Electronics and Communication Engineering, 4(4): 794-797.

[6] Vidhale, A.A., Palekar, A.D., Kanchan, A.G. (2014). Automated pantry car system. International Journal of Advanced Research in Computer Science and Software Engineering, 4(2): 692-699.

[7] Alam, M.S., Muthiah, A., Salve, U.R. (2019). Thermal comfort of the kitchen in pantry cars on Indian railways. Instrumentation Mesure Métrologie, 18(5): 465-477. https://doi.org/10.18280/i2m.180506

[8] Yang, T., Wright, N.G., Etheridge, D.W., Quinn, A.D. (2006). A comparison of CFD and full-scale measurements for analysis of natural ventilation. International Journal of Ventilation, 4(4): 337-348. http://dx.doi.org/10.1080/14733315.2005.11683713

[9] Sabtalistia, Y.A., Ekasiwi, S.N.N., Iskandriawan, B. (2014). Effect of air conditioning position on thermal comfort in the floor air conditioning system. In Applied Mechanics and Materials, 493: 74-79. https://doi.org/10.4028/www.scientific.net/AMM.493.7 4

[10] Noman, F.G., Kamsah, N., Kamar, H.M. (2016). Improvement of thermal comfort inside a mosque building. Jurnal Teknologi, 78(8): 9-18. https://doi.org/10.11113/jt.v78.9579

[11] American Society of Heating, Refrigerating and AirConditioning Engineers. (2004). Thermal environmentalconditions for human occupancy, Atlanta: ASHRAEStandard-55. http://www.ditar.cl/archivos/Normas ASHRAE/T0080 ASHRAE-55-2004-ThermalEnviromCondiHO.pdf.

[12] Tap, M.M., Kamar, H.M., Marsono, A.K., Kamsah, N., Salimin, K.A.M. (2011). Simulation of thermal comfort of a residential house. International Journal of Computer Science Issues, 8(5): 200-208.

[13] Nugroho, A.M., Ahmad, M.H., Ossen, D.R. (2007). A preliminary study of thermal comfort in Malaysia' $\mathrm{s}$ single storey terraced houses. Journal of Asian Architecture and Building Engineering, 6(1): 175-182. https://doi.org/10.3130/jaabe.6.175

[14] Karyono, T.H., Sri, E., Sulistiawan, J.G., Triswanti, Y. (2015). Thermal comfort studies in naturally ventilated buildings in Jakarta, Indonesia. Buildings, 5(3): 917-932. https://doi.org/10.3390/buildings5030917

[15] Zare, S., Hasheminejad, N., Shirvan, H.E., Hemmatjo, R. Sarebanzadeh, K., Ahmadi, S. (2018). Comparing Universal Thermal Climate Index (UTCI) with selected thermal indices/environmental parameters during 12 months of the year. Weather and Climate Extremes, 19: 49-57. https://doi.org/10.1016/j.wace.2018.01.004

[16] Zare, S., Hasheminejad, N., Bateni, M., Baneshi, M.R., Shirvan, H.E., Hemmatjo, R. (2020). The association between wet-bulb globe temperature and other thermal indices (DI, MDI, PMV, PPD, PHS, PSI and PSIhr): A field study. International Journal of Occupational Safety and Ergonomics, 26(1): 71-79. https://doi.org/10.1080/10803548.2018.1475957

[17] Zare, S., Hasheminezhad, N., Sarebanzadeh, K., Zolala, F., Hemmatjo, R., Hassanvand, D. (2018). Assessing 
thermal comfort in tourist attractions through objective and subjective procedures based on ISO 7730 standard: A field study. Urban Climate, 26: 1-9. https://doi.org/10.1016/j.uclim.2018.08.001

[18] Cheung, T., Schiavon, S., Parkinson, T., Li, P., Brager, G. (2019). Analysis of the accuracy on PMV-PPD model using the ASHRAE Global Thermal Comfort Database II. Building and Environment, 153: 205-217. https://doi.org/10.1016/j.buildenv.2019.01.055

[19] Fabbri, K. (2013). Thermal comfort evaluation in kindergarten: PMV and PPD measurement through datalogger and questionnaire. Building and Environment, 68: 202-214. https://doi.org/10.1016/j.buildenv.2013.07.002

[20] Lau, S.S.Y., Zhang, J., Tao, Y. (2019). A comparative study of thermal comfort in learning spaces using three different ventilation strategies on a tropical university campus. Building and Environment, 148: 579-599. https://doi.org/10.1016/j.buildenv.2018.11.032

[21] Simone, A., Olesen, B.W., Stoops, J.L., Watkins, A.W. (2013). Thermal comfort in commercial kitchens (RP1469): Procedure and physical measurements (Part 1). Hvac\&r Research, 19(8): 1001-1015. https://doi.org/10.1080/10789669.2013.840494

[22] Simone, A., Olesen, B.W. (2013). Thermal environment evaluation in commercial kitchens of United States. In Clima 2013: 11th REHVA World Congress \& 8th International Conference on IAQVEC.

[23] Zhou, B., Chen, F., Dong, Z., Nielsen, P.V. (2016). Study on pollution control in residential kitchen based on the push-pull ventilation system. Building and Environment, 107:

99-112 https://doi.org/10.1016/j.buildenv.2016.07.022

[24] Chen, Z., Xin, J., Liu, P. (2020). Air quality and thermal comfort analysis of kitchen environment with CFD simulation and experimental calibration. Building and Environment, 172: 106691 https://doi.org/10.1016/j.buildenv.2020.106691

[25] Manshoor, B., Zaman, I., Asmuin, N., Ramlan, F., Khalid, A. (2014). Optimizing of make up air performance for commercial kitchen ventilation improvement. In MATEC Web of Conferences, 13(1): 03002. https://doi.org/10.1051/matecconf/20141303002

[26] Hamidur Rahman, M., Sadrul Islam, A.K.M. (2016). Effects of the position of kitchen hood suction on thermal comfort and carbon dioxide gas emission from an urban residential kitchen in developing countries. In Applied Mechanics and Materials, 819: 117-121. https://doi.org/10.4028/www.scientific.net/AMM.819.1 17

[27] Malek, N.A., Khairuddin, M.H., Rosli, M.F. (2015). Thermal comfort investigation on a naturally ventilated two-storey residential house in Malaysia. In IOP Conference Series: Materials Science and Engineering, 88(1): $\quad 012014 . \quad$ https://doi.org/10.1088/1757$899 X / 88 / 1 / 012014$

[28] Nazarian, N., Fan, J., Sin, T., Norford, L., Kleissl, J. (2017). Predicting outdoor thermal comfort in urban environments: A 3D numerical model for standard effective temperature. Urban Climate, 20: 251-267. https://doi.org/10.1016/j.uclim.2017.04.011

[29] Han, J., Zhang, G., Zhang, Q., Zhang, J., Liu, J., Tian, L., Zheng, C., Hao, J., Lin, J., Liu, Y., Moschandreas, D.J. (2007). Field study on occupants' thermal comfort and residential thermal environment in a hot-humid climate of China. Building and Environment, 42(12): 4043-4050. https://doi.org/10.1016/j.buildenv.2006.06.028

[30] Shetty, S.S., Chinh, H.D., Gupta, M., Panda, S.K. (2016). Personal thermal comfort management in existing office buildings using energy-efficient fans. In IECON 201642nd Annual Conference of the IEEE Industrial Electronics Society, Florence, Italy, pp. 7083-7088. https://doi.org/10.1109/IECON.2016.7793711

[31] Alam, M.S., Arunachalam, M., Salve, U.R. (2020). A Comparative analysis between indoor and outdoor thermal comfort parameters of railway pantry car. KIIT Thermo 2020 - International Conference on Thermofluids, pp. 411-416. https://doi.org/10.1007/978981-15-7831-1 37

[32] Mak, C.M., Yik, F.W. (2002). A study of natural ventilation in a kitchen using computational fluid dynamics (CFD). Architectural Science Review, 45(3): 183-190. https://doi.org/10.1080/00038628.2002.9697509

[33] Abanto, J., Reggio, M. (2006). Numerical investigation of the flow in a kitchen hood system. Building and Environment, 41(3): 288-296. https://doi.org/10.1016/j.buildenv.2005.01.035

[34] Ren, R.S., Jiang, D.H., Shi, F.E., Zhao, Y.C. (2012). Flow field characteristics simulation of the exhaust hood. In Advanced Materials Research, 557-559: 2261-2265. https://doi.org/10.4028/www.scientific.net/AMR.557559.2261

[35] Saha, S., Guha, A., Roy, S. (2012). Experimental and computational investigation of indoor air quality inside several community kitchens in a large campus. Building and Environment, 52: 177-190. https://doi.org/10.1016/j.buildenv.2011.10.015

[36] Fujimura, N., Kotani, H., Yamanaka, T., Momoi, Y., Sagara, K., Masui, K. (2017). C\&C efficiency of canopy hood exposed to horizontal air stream in commercial kitchen calculated by CFD analysis. International Journal of Ventilation, 16(3): 213-229. https://doi.org/10.1080/14733315.2017.1299517

[37] Yahya, M.N.R., Amin, M.A.M., Ismail, M.I., Razlan, Z.M., Bakar, S.A., Khairunizam, W., Zunaidi, I. (2019). Numerical analysis on modelling thermal comfort minor operation theatre. In Journal of Physics: Conference Series, 1372: 012033. https://doi.org/10.1088/17426596/1372/1/012033

[38] Brannigan, F.L., Bright, R.G. and Jason, N.H. (1980). Fire investigation handbook (Vol. 134). US Department of Commerce, National Bureau of Standards.

[39] Hussin, A., Salleh, E., Chan, H.Y., Mat, S. (2014). Thermal comfort during daily prayer times in an airconditioned mosque in Malaysia. In Proceedings of 8th Windsor Conference: Counting the Cost of Comfort in a Changing World, pp. 10-13.

[40] Zomorodian, Z.S., Tahsildoost, M., Hafezi, M. (2016). Thermal comfort in educational buildings: A review article. Renewable and Sustainable Energy Reviews, 59: 895-906. https://doi.org/10.1016/j.rser.2016.01.033

[41] Kamar, H.M., Kamsah, N.B., Ghaleb, F.A., Alhamid, M.I. (2019). Enhancement of thermal comfort in a large space building. Alexandria Engineering Journal, 58(1): 49-65. https://doi.org/10.1016/j.aej.2018.12.011

[42] American Society of Heating, Refrigerating and AirConditioning Engineers. (1992). Thermal environmental 
conditions for human occupancy, ASHRAE Standard-55. https://archive.org/stream/ASHRAE551992/ASHRAE55-1992_djvu.txt.

[43] American Society of Heating, Refrigerating and AirConditioning Engineers. (2013). Thermal environmental conditions for human occupancy, ASHRAE Standard-55. https://www.ashrae.org/File\%20Library/Technical\%20 Resources/Standards\%20and\%20Guidelines/Standards \%20Addenda/55_2013_b_20141209.pdf.
[44] Alam, M.S., Muthiah, A., Salve, U.R. (2020). Thermal comfort study in Indian railway pantry cars kitchen. Instrumentation Mesure Métrologie, 19(4): 289-295. https://doi.org/10.18280/i2m.190406

[45] Alam, M.S., Muthiah, A., Salve, U.R. (2020). Appraisal of thermal comfort in non-air-conditioned and airconditioned railway pantry car kitchens. International Journal of Integrated Engineering, 12(8): 318-327. https://doi.org/10.1063/5.0024528 